\title{
Paleoenvironmental conditions at Core KC01B (Ionian Sea) through MIS 13-9: Evidence from calcareous nannofossil assemblages
}

\author{
Patrizia Maiorano $^{\mathrm{a}, *}$, Francesca Tarantino ${ }^{\mathrm{a}}$, Maria Marino ${ }^{\mathrm{a}}$, Gert J. De Lange ${ }^{\mathrm{b}}$ \\ ${ }^{a}$ Dipartimento di Scienze della Terra e Geoambientali, Università degli Studi di Bari Aldo Moro, Italy \\ ${ }^{\mathrm{b}}$ Department of Earth Sciences-Geochemistry, Utrecht University, The Netherlands
}

\section{A R T I C L E I N F O}

Article history:

Available online 10 December 2011

\begin{abstract}
A B S T R A C T
Quantitative analyses on calcareous nannofossil assemblages on high temporal resolution (600-800 years) have been carried out from Core KC01B in the Ionian Sea (Eastern Mediterranean) throughout Marine Isotope Stage (MIS) 13-9, between 500 and $300 \mathrm{ka}$. This is an interval of considerable climate changes, known as the Mid-Brunhes event, which includes MIS 11, considered as a possible analogue for future interglacial conditions. In the Mediterranean core, the interval is characterized by the dominance of Gephyrocapsa spp., as also known from ocean records. Calcareous nannofossil abundance fluctuations have been interpreted in terms of modification of sea surface primary productivity/water stratification and temperature. Specifically, the increase in abundance of Gephyrocapsa caribbeanica and small Gephyrocapsa coupled with decreases of Florisphaera profunda, Syracosphaera spp. and Rhabdosphaera spp. suggests enhanced primary productivity/mixed surface waters during interglacial stages and at the Terminations, which can be interpreted in terms of interaction between climate changes and mesoscale oceanographic circulation. On the other hand, distributions of Calciosolenia spp., Oolithotus spp. and Umbilicosphaera sibogae, which are in phase with $\delta^{18} \mathrm{O}$ curve showing higher abundances at the lighter values of the marine isotope record, are considered as warm-water indicators.

Biotic proxies point to peculiar climate dynamics through the MIS 12-11 transition (i.e. Termination V). High productive, cool, low salinity and turbid surface waters characterize the early MIS 11 (421-408 ka) and likely reflect enhanced continental humidity/monsoon activity over North Africa and increased runoff into the basin. A late surface water warming with respect to Termination V is established at about $403 \mathrm{ka}$, during a period of low insolation forcing, almost coeval with the deposition of sapropel S11. A climate optimum, lasting about $15 \mathrm{ky}$ (403-389 ka), is then recorded during a period of low insolation forcing centred at $398 \mathrm{ka}$. The later part of MIS 11 is characterized by climate deterioration at about $389 \mathrm{ka}$. Comparison with results from subtropical to polar Atlantic records suggests a remarkable relation between Mediterranean and Atlantic climate regimes.
\end{abstract}

(c) 2011 Elsevier Ltd and INQUA. All rights reserved.

\section{Introduction}

Calcareous nannofossil assemblages have been analysed at the Eastern Mediterranean Core KC01B (Ionian Sea) through Marine Isotope Stages (MIS) 13-9, between 500 and $300 \mathrm{ka}$. This time interval includes the Mid-Brunhes Event (MBE, Jansen et al., 1986), a period of significant climate modification and perturbation of the global ocean carbon system. It is characterized by enhanced warmth during interglacial phases after MIS 13 (EPICA community members, 2004; Jouzel et al., 2007), an increase in atmospheric $\mathrm{CO}_{2}$ at levels similar to the pre-industrial Holocene (Siegenthaler et al., 2005), large accumulation of neritic and pelagic carbonate at low and high latitude (Howard and

\footnotetext{
* Corresponding author.

E-mail address: p.maiorano@geo.uniba.it (P. Maiorano).
}

Prell, 1994; Howard, 1997; Shipboard Scientific Party, 1997; Hodell et al., 2000), and overall poor carbonate preservation (Crowley, 1985; Droxler et al., 1988, 1997; Wu et al., 1991; Bassinot et al., 1994; Droxler and Farrell, 2000; Hodell et al., 2000). A dominance of the genus Gephyrocapsa among calcareous nannofossils have been also documented in this interval (Bollmann et al., 1998; Baumann and Freitag, 2004) and suggested as a possible cause of the enhanced pelagic carbonate production (Barker et al., 2006).

The MIS 12-11 transition (Termination $\mathrm{V}$ ) is part of this peculiar interval and represents the largest amplitude change in the marine isotope composition of the last $5 \mathrm{Ma}$ (Droxler and Farrell, 2000; Droxler et al., 2003). In addition, MIS 11 is known as an unusually longlasting interglacial (Petit et al., 1999; Hodell et al., 2000; McManus et al., 2003; Masson-Delmotte et al., 2006; Jouzel et al., 2007). Several studies have focused on MIS 11 as a potential analogue of the 
Holocene, due to the similar atmospheric composition and orbital configuration characterized by low eccentricity and weak precession forcing (e.g. Loutre and Berger, 2003; EPICA community members, 2004; Ruddiman, 2005). Therefore, it is considered a suitable candidate to predict the natural evolution of the present interglacial. During MIS 11, sea level has been suggested to be up to $20 \mathrm{~m}$ above the current level (Hearty et al., 1999; Kindler and Hearty, 2000) or close to the Holocene highstand (Rohling et al., 2009; Bowen, 2010). Other controversies still remain on the magnitude of the warming of this interglacial and on the real analogy of the climate conditions between MIS 11 and the Holocene (Bauch et al., 2000; Hodell et al., 2000; Bauch and Erlenkeuser, 2003; Helmke and Bauch, 2003; de Abreu et al., 2005; Kandiano and Bauch, 2007; Helmke et al., 2008; Rohling et al., 2010).

In order to improve the temporal and spatial paleoenvironmental framework during this important climate interval, calcareous nannofossil assemblages were analysed in high temporal resolution, from a key Eastern Mediterranean marine archive. The Mediterranean Basin, due to its peculiar physiography, is particularly sensitive to record climate perturbations. It is a landlocked semi-enclosed basin which resides at the transition between the subtropical and high/mid-latitude atmospheric systems. Its climate conditions depend on the latitudinal shift between the influence of temperate westerlies that dominate over central and northern parts of Europe, and the atmospheric subtropical high pressure belt over North Africa (Boucher, 1975; Lolis et al., 2002). Due to its mid-latitude position, the Mediterranean region is also a key location to investigate climatic connections between high and low latitudes. The studied core represents a reference marine record for the Mediterranean and specifically for planktonic foraminifera $\delta^{18} \mathrm{O}$ isotope chronology, and for the sapropel-tuned astronomical timescale for the last 1.1 Ma (Lourens, 2004).

Coccolithophorids are one of the dominant phytoplankton components in the Ionian Sea (Malinverno et al., 2003). They represent the main contributor to the biogenic carbonate flux in the central Eastern Mediterranean (Ziveri et al., 2000) and are abundant in the surface sediments (Knappertsbusch, 1993). The composition of the assemblage reflects characteristics of surface water such as temperature, nutrient content, salinity and turbidity (McIntyre and Bè, 1967; Brand, 1994; Winter et al., 1994) and therefore represents a valuable tool to describe modifications in surface water features. However, knowledge on the ecological behaviour of different species is still not well established and mostly concerns oceanic areas. Quantitative patterns of middle Pleistocene calcareous nannofossils are presented in the attempt to improve paleoecological meaning of some of the taxa in the investigated area and provide paleoenvironmental reconstruction during a key climate interval.

The calcareous nannofossil results presented in this paper represent part of an ongoing multidisciplinary project based on both biotic and abiotic proxies which has the final goal to provide a high resolution paleoclimate frame in the Ionian Sea during a period of significant climate variability. The acquired data represent the first high temporal resolution calcareous nannofossil data-set in the Mediterranean Sea during this key climate interval.

\section{Oceanographic setting}

The Mediterranean is a landlocked marginal sea connected to the Atlantic Ocean through the narrow Strait of Gibraltar (Fig. 1). It is composed of two sub-basins, Western and Eastern Mediterranean, connected by the Strait of Sicily. The negative fresh-water and heat budget force its anti-estuarine thermohaline basin scale circulation that results in nutrient-poor surface inflow and saltier, nutrient-richer deeper water outflow through the straits of Gibraltar (Bethoux et al., 1992). The Atlantic Water (AW) enters into the Mediterranean through the Strait of Gibraltar and travels eastward as Modified Atlantic Water (MAW) which is restricted to a surface layer about $200 \mathrm{~m}$ thick. As it spreads eastward throughout the basin, it becomes saltier due to continued evaporation (Wüst, 1961; Malanotte-Rizzoli and Hecht, 1988). A combination of heat loss and evaporation in surface waters creates vertical convection and the consequent formation of Levantine Intermediate Water (LIW)

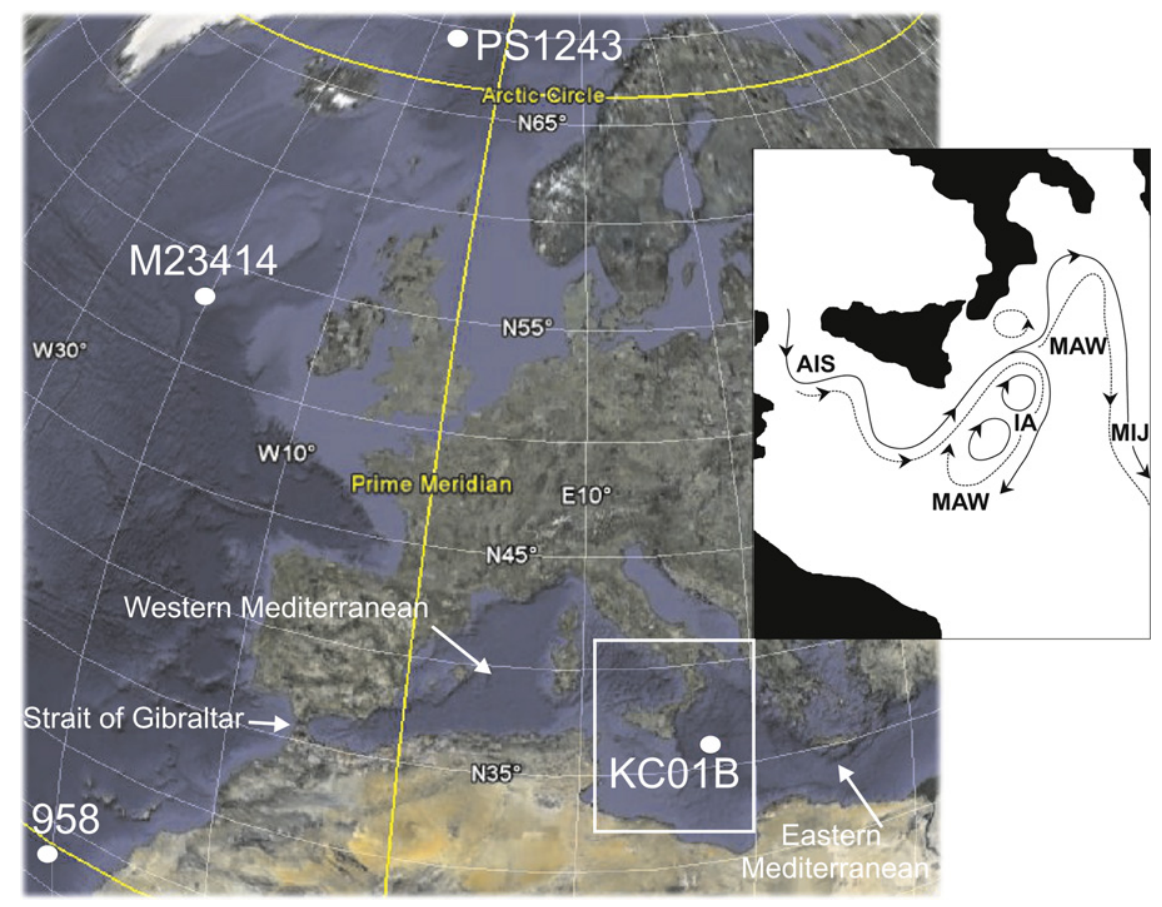

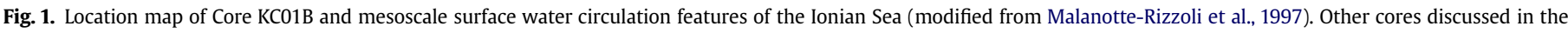
text are also indicated. AIS: Atlantic-Ionian Stream; MAW: Modified Atlantic Water; IA: Ionian Anticyclones; MIJ: Mid Ionian Jet. 
(Malanotte-Rizzoli and Hecht, 1988; Lascaratos et al., 1993) which flows westward in an intermediate layer between 200 and $600 \mathrm{~m}$ (Mediterranean Intermediate Water - MIW) and forms the main component of the salty Mediterranean outflow water. The Western and Eastern basin each have their own source of deep water (Eastern and Western Mediterranean Deep Water - EMDW and WMDW), which resides below the MIW. On a sub-basin scale, the present-day Eastern Mediterranean general circulation of the upper thermocline is characterized by energetic jets, meandering currents and gyres (Malanotte-Rizzoli and Bergamasco, 1991; Robinson et al., 1991; POEM Group, 1992; Malanotte-Rizzoli et al., 1999) having seasonal and interannual wind forcing variability (Pinardi and Navarra, 1993; Molcard et al., 2002). The MAW enters into the Eastern basin through the Strait of Sicily (Fig. 1) carried by the Atlantic-Ionian stream (AIS) jet-like current (Malanotte-Rizzoli et al., 1997). After entering the Strait of Sicily, the AIS describes a strong meander that protrudes northward into the Ionian Sea. One branch of the AIS turns southward and envelops a broad antyciclonic area (Ionian Anticyclone IA); the other branch extends northward and then turns southward crossing meridionally the Ionian Sea (Fig. 1). Mesoscale eddies and meanders also occur and interact with the sub-basin scale circulation. The AIS, entering through the Sicily Straits, has a more southward route during winter, while protrudes northward into the Ionian interior during summer (Malanotte-Rizzoli and Bergamasco, 1991; Robinson et al., 1992; Robinson and Golnaraghi, 1993). However, complex dynamics of the AIS at the entrance of the Ionian Sea and a seasonal and interannual variability in the amplitude, strength and location of the gyres have been inferred from both historical in situ and satellite observations and modelling studies (e.g. Robinson et al., 1992, 1999; Roussenov et al., 1995; MalanotteRizzoli et al., 1997; Astraldi et al., 1999; Lermusiaux and Robinson, 2001; Fusco et al., 2003; Pinardi et al., 2006). In addition, complex meteorological, oceanic and hydrological phenomena are believed to modify the deep water source in the Eastern Mediterranean, causing the genesis of the Eastern Mediterranean Transient (Roether et al., 1996; Klein et al., 1999; Malanotte-Rizzoli et al., 1999) and thus affecting the circulation of the intermediate and deep layers.

With regards to the trophic regimes, the Mediterranean Basin has a well recognized oligotrophic nature (Sournia, 1973), more pronounced in its eastern part (Krom et al., 1991, 2003). Besides the general oligotrophic pattern, mesoscale features may affect biological processes (e.g. Estrada, 1996). Seasonal variability is well recognized: mesotrophic conditions develop during winter as a result of vertical mixing or coastal upwelling which provide vertical transport of nutrients into the photic zone; on the other hand, the oligotrophic regime prevails in the summer season due to stable thermal stratification and deepening of summer thermocline (Krom et al., 1992, 1993; Crispi et al., 1999; Allen et al., 2002; Siokou-Frangou et al., 2010). Modification in the vertical distribution of water masses is also known to be responsible of the rising of the nutricline depth within the euphotic layer (Klein et al., 1999) with possible influence on biological productivity.

\section{Core material and chronology}

The piston Core KC01B (37.04 m long) was recovered from the southern Calabrian Ridge (Ionian Basin, $36^{\circ} 15.25^{\prime} \mathrm{N}, 17^{\circ} 44.34^{\prime} \mathrm{E}$, $3643 \mathrm{~m}$ water depth) during cruise MD69 of the French R/V Marion Dufresne in 1991. The lithology consists of hemipelagic marls with interbedded sapropels, tephra and turbidite sandy layers (Castradori, 1993; Sanvoisin et al., 1993; Langereis et al., 1997).

The time-frame of the core was initially based on the astronomical calibration of sapropels by Langereis et al. (1997). An independent age model, based on the marine isotope record, was then proposed by Rossignol-Strick et al. (1998). Afterwards, Lourens
(2004) established an improved sapropel-tuned age model of the core based on high resolution colour reflectance correlation with Ocean Drilling Project (ODP) Site 964. The latter tuning resulted in a revised chronology of the marine isotope record of Rossignol-Strick et al. (1998) which fits well with other Mediterranean and open ocean marine isotope records (Fig. 2) and has been adopted in the present study through MIS 13-9. In the investigated interval, the new isotope chronology of Core KC01B highlights a notable pattern of the $\delta^{18} \mathrm{O}_{\mathrm{G} \text {. ruber }}$ during MIS 12 (Lourens, 2004): a strong depletion in the $\delta^{18} \mathrm{O}_{G}$. ruber, previously included in MIS 11 (Rossignol-Strick et al., 1998), occurs during the glacial stage and represents the interstadial stage 12.3 (Fig. 2). This marine isotope excursion, which is absent in global ice volume records, most likely reflects an episode of decreased sea surface water salinity caused by fresh water supply, suggesting peculiar circum-Mediterranean climate changes during glacial conditions (Lourens, 2004).

\section{Method}

Calcareous nannofossils have been analysed from 298 samples through the sections 15-21 of Core KC01B between $1584.5 \mathrm{~cm}$ and $2241.5 \mathrm{~cm}$ cpd (corrected piston depth). Sample spacing was about $2 \mathrm{~cm}$ in order to obtain approximately a temporal resolution of one sample per $600-800$ years. Simple smear slides were prepared from unprocessed samples according to the standard technique (Bown and Young, 1998) and analysed under a polarized light microscope at a magnification of $1000 \times$. Quantitative analyses have been performed by counting about 300 nannofossils $>3 \mu \mathrm{m}$ in size in a variable number of fields of view. In the same fields of view needed for counting 300 nannofossils $>3 \mu \mathrm{m}$, abundances of nannofossils $<3 \mu \mathrm{m}$, which include small placoliths (small Gephyrocapsa and reticulofenestrids $<3 \mu \mathrm{m}$ ) and holococcoliths, have been counted separately, following Flores et al. (2000a). The two different counting methods have been applied as small- and medium-sized gephyrocapsids are the dominant component of the assemblages, and therefore a single count of the total assemblage may had prevented the identification of those taxa (i.e. Calciosolenia, Helicosphaera, Syracosphaera, Rhabdosphaera, Umbilicosphaera and Oolithotus) having lower abundance in the assemblage, although valuable as tools for paleoenvironmental interpretations.

In addition, due to their peculiar deep-photic habitat, Florisphaera profunda and Gladiolithus flabellatus have been also evaluated in this separate counting (Matsuoka and Okada, 1989; Castradori, 1993), as well as reworked taxa. Consequently, a total of about 600-700 nannofossils has been considered in each sample. Abundances of nannofossils $>3 \mu \mathrm{m}$ have been plotted both as percentages with respect to the total nannofossil assemblage and to 300 nannofossils $>3 \mu \mathrm{m}$ in order to compare different counting procedures. In order to estimate diversity of the total assemblage, the Shannon-Weaver index was computed using PAST (PAleontology STatistic) software (Hammer et al., 2001).

A multivariate statistical analyses using Principal Component Analysis (PCA) as extraction method was carried out in order to clarify the relationship between coccolith distribution and paleoenvironmental variables. The software StatView 5.0.1 for Windows was used for this procedure. The data sets contain percentage in abundance of the most common taxa with respect to the total nannofossil assemblage. The abundances of Pseudoemiliania lacunosa has been omitted since its distribution is stratigraphically controlled. In addition, those taxa which are present only sporadically in the counting (see below) have also been excluded.

The well known $\mathrm{N}$ ratio paleoproductivity proxy has been also considered, following Flores et al. (2000a) and compared with other paleoenvironmental signals obtained in the present study. The $\mathrm{N}$ ratio has been calculated according to the function 


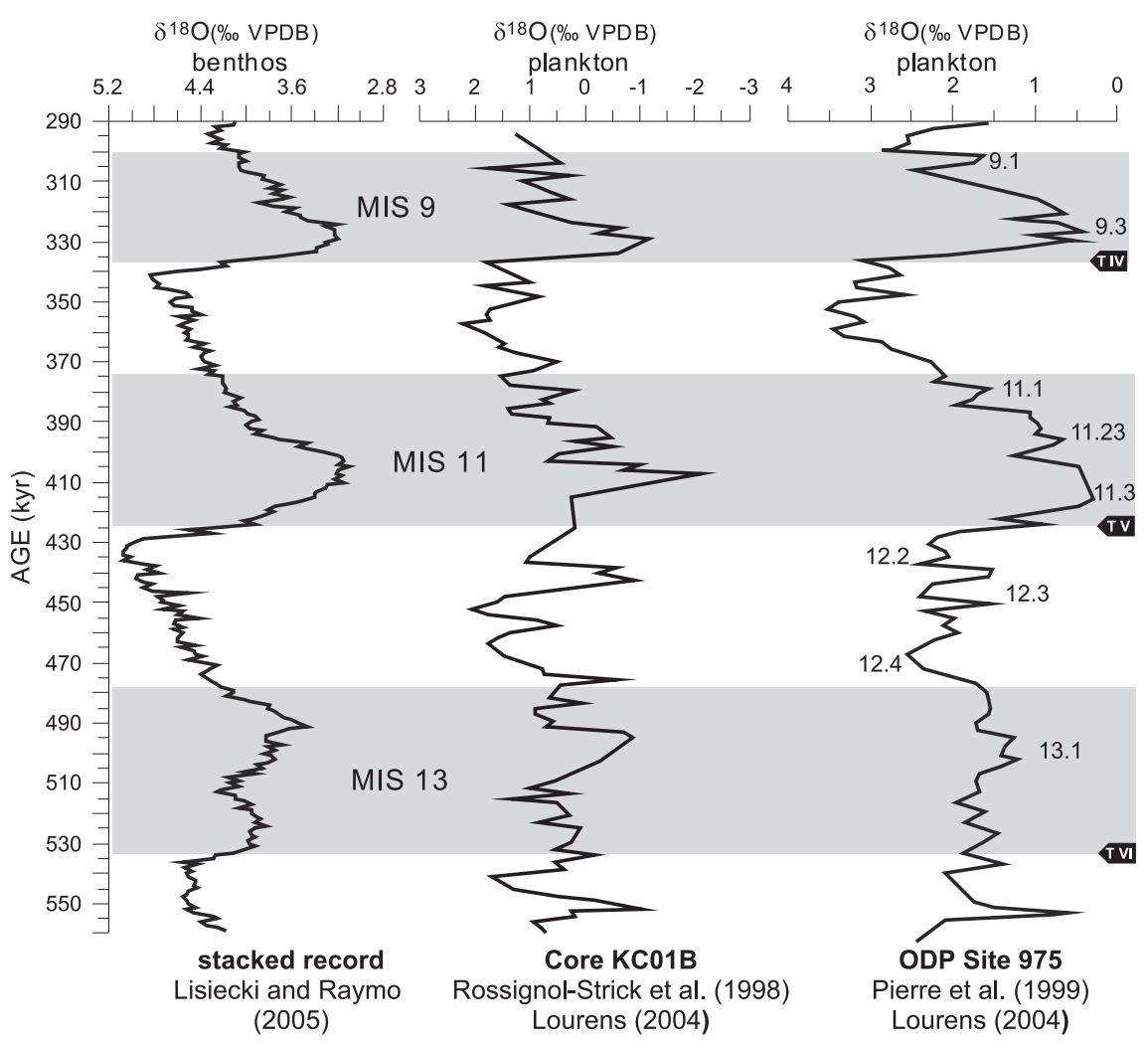

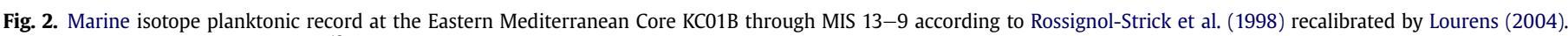

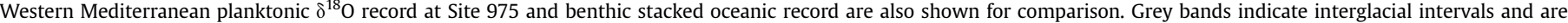
traced according to marine isotope chronology of Lisiecki and Raymo (2005).

$N=R /(R+F)$

where $R$ is \% of small placoliths, and $F$ is \% of $F$. profunda. High values in the $N$ index (values closer to 1 ) indicate upwelling and shallow nutricline/thermocline position while low values (values closer to 0 ) imply weak upwelling and relatively deep nutricline/thermocline position.

With regards to taxonomic criteria, a complete list of the taxa considered in this study is included in the Appendix. In addition, the morphological features adopted in this study for the gephyrocapsids, whose terminology is often confusing, is reported in Table 1, together with equivalences of Gephyrocapsa species and morphotypes adopted by other authors.

\section{Results}

\subsection{Biostratigraphy}

The stratigraphic interval investigated in the present paper falls within Martini's (1971) Standard Zones NN19 and NN20. It is also correlated with the Gephyrocapsa caribbeanica Acme Zone (Weaver, 1993; Hine and Weaver, 1998), an interval dominated by G. caribbeanica and defined at the base by the reduction in abundance of small Gephyrocapsa (mainly Gephyrocapsa aperta and small specimens of $G$. caribbeanica plus other small Gephyrocapsa spp.) and at the top by the base of the G. aperta Acme. This zone spans the interval from the lower part of MIS 8 to 15 (Weaver, 1993).

Table 1

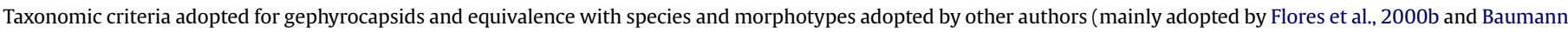
and Freitag, 2004).

\begin{tabular}{|c|c|c|c|c|}
\hline This study & small Gephyrocapsa & G. oceanica & G. caribbeanica & G. margereli/G. muellerae \\
\hline Maximum coccolith lengh & $<3 \mu \mathrm{m}$ & $3.5-5.5 \mu \mathrm{m}$ & $>3 \mu \mathrm{m}$ & $3-4 \mu \mathrm{m}$ \\
\hline Bridge angle & 1 & $>50^{\circ}$ & Closed central area & $<40^{\circ} \mid<25^{\circ}$ \\
\hline \multicolumn{5}{|l|}{ Author equivalence } \\
\hline Bréhéret (1978) & G. ericsonii, G. aperta & G. oceanica & G. caribbeanica & G. margereli/G. muellerae \\
\hline Samtleben (1980) & Several species & G. oceanica & G. caribbeanica & G. margereli/G. muellerae \\
\hline Raffi et al. (1993) & small Gephyrocapsa & medium Gephyrocapsa spp. & G. caribbeanica s.l. & small Gephyrocapsa \\
\hline Weaver (1993) & $\begin{array}{l}\text { G. aperta, small G. caribbeanica } \\
\text { and small Gephyrocapsa spp. }\end{array}$ & & & \\
\hline Pujos and Giraudeau (1993) & small Gephyrocapsa & “open” Gephyrocapsa & “closed" Gephyrocapsa & \\
\hline Bollmann (1997) & Gephyocapsa minute & $\begin{array}{l}\text { Gephyrocapsa equatorial } \\
\text { Gephyrocapsa large }\end{array}$ & Gephyrocapsa oligotrophic & $\begin{array}{l}\text { Gephyrocapsa } \\
\text { transitional/Gephyrocapsa cold }\end{array}$ \\
\hline Flores et al. (2000b) & small Gephyrocapsa & G. oceanica & G. caribbeanica & -/G. muellerae \\
\hline Baumann and Freitag (2004) & G. ericsonii, G. aperta & G. oceanica & G. caribbeanica & G. margereli/G. muellerae \\
\hline
\end{tabular}


Biostratigraphic features of Core KC01B have been widely discussed by Castradori (1993) and are not the main focus of the present paper. However, in the investigated interval, the Last Occurrence (LO) of $P$. lacunosa, a widely documented bioevent, has been detected, and therefore the updated biochronology of the event at the core is here provided. As shown in Fig. 3, the taxon has a significant decrease in abundance during MIS 12 where the LO event defines the NN19/NN20 zonal boundary. It has an age of 0.465 Ma which is in good accordance with Eastern Mediterranean records where the event has been dated at $0.467 \mathrm{Ma}$ (Raffi et al., 2006). Above the LO event, a tail of rare and scattered occurrences of the taxon is recorded up to the top of the studied interval, considered as due to reworking. From a stratigraphic point of view, in addition to P. lacunosa, the distribution of Helicosphaera inversa appears quite significant. This taxon is mostly restricted to MIS 11 , with only very rare occurrences during MIS 12. The distribution of this species is poorly known from oceanic records and is still unknown in the Mediterranean area. First Appearance Datum (FAD) and Last Appearance Datum (LAD) of the species have been dated at 0.48 and 0.15 Ma respectively as proposed by Takayama and Sato (1987) and Sato and Takayama (1992). Different ages and distributions have been also recorded by Matsuoka and Okada (1989), Hine and Weaver (1998) and Marino et al. (2003). According to the results (Fig. 3) H. inversa only occurs from 0.450 to $0.371 \mathrm{Ma}$, although a more continuous distribution is limited to MIS 11. Further investigations on the distribution of $H$. inversa may be constructive in future studies in order to test the possible utility of this taxon as a marker species within the Mediterranean.

\subsection{Calcareous nannofossil assemblage}

Assemblage preservation is variable from excellent to slightly etched, following the classification of Bown and Young (1998). Dissolution phenomena have been observed mostly in samples within glacial phases (Fig. 4) and are mostly observed in the central areas of a few specimens. Among the most abundant taxa are small placoliths, G. caribbeanica, Gephyrocapsa margereli/muellerae and F. profunda (Fig. 4). Small placoliths generally constitute $25-30 \%$ of the assemblage and show several short amplitude fluctuations. F. profunda is quite significant in the assemblage with abundances of about 25\%. The taxon shows distinct decreases at MIS 12-11 and MIS 10-9 transitions where it reaches abundances lower than $10 \%$, generally ranging between 3 and $5 \%$. G. caribbeanica represents an important component of the assemblage, having abundances which may also reach $50 \%$. The taxon displays a peculiar distribution pattern showing major abundances during interglacials and at the MIS 12-11 transition (Fig. 4). G. margereli/muellerae occurs continuously through the interval (about 25\% in abundance). Within this group, the most abundant specimens consist of Gephyrocapsa 3-4 $\mu \mathrm{m}$ with bridge angle between $25^{\circ}$ and $40^{\circ}$ (mostly close to $40^{\circ}$ ) and therefore belonging to G. margereli (Table 1, Fig. 7). However, rare specimens of Gephyrocapsa muellerae, having bridge angles $<25^{\circ}$ (Table 1), also occur (Fig. 7) although they are not easily distinguishable under the polarized light microscope. The investigated interval is a period of evolutionary change between G. margereli and G. muellerae (Samtleben, 1980) and this may further prevent the unambiguous recognition of the two species: G. muellerae becomes dominant in the

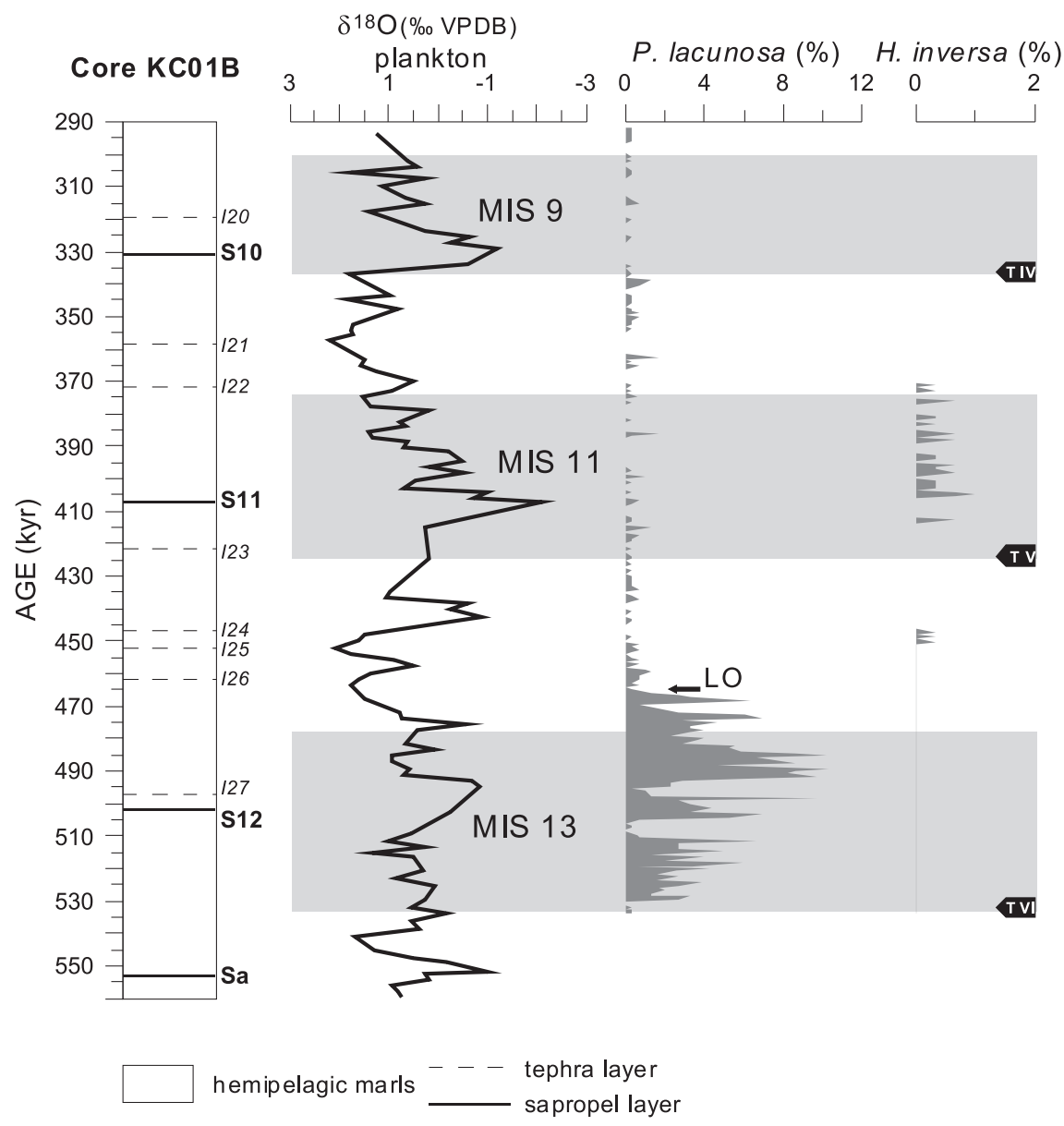

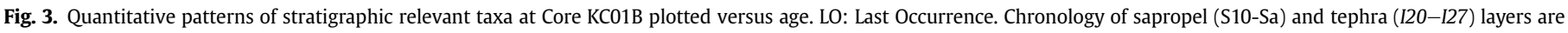
according to Lourens (2004). Grey bands indicate interglacial intervals and are traced according to marine isotope chronology of Lisiecki and Raymo (2005). 


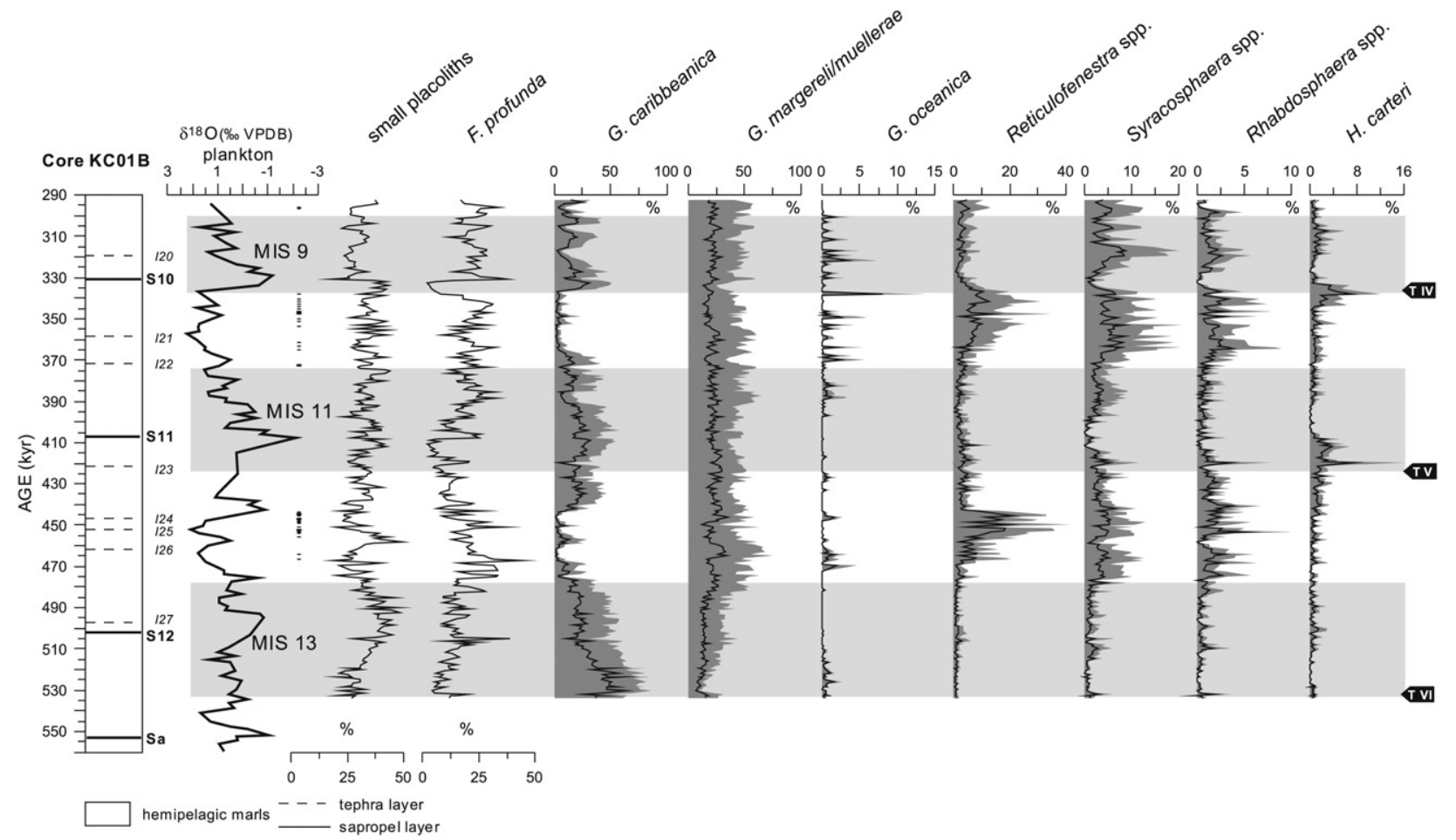

Fig. 4. Quantitative patterns of calcareous nannofossils at Core KC01B through MIS 13-9 plotted versus age. Abundances are plotted as percentages of the total assemblage (black line) and of 300 nannofossils $>3 \mu \mathrm{m}$ (grey area). Samples with dissolution evidences (-) are indicated. Chronology of sapropel (S10-Sa) and tephra (I20-I27) layers are according to Lourens (2004). Grey bands indicate interglacial intervals and are traced according to marine isotope chronology of Lisiecki and Raymo (2005).

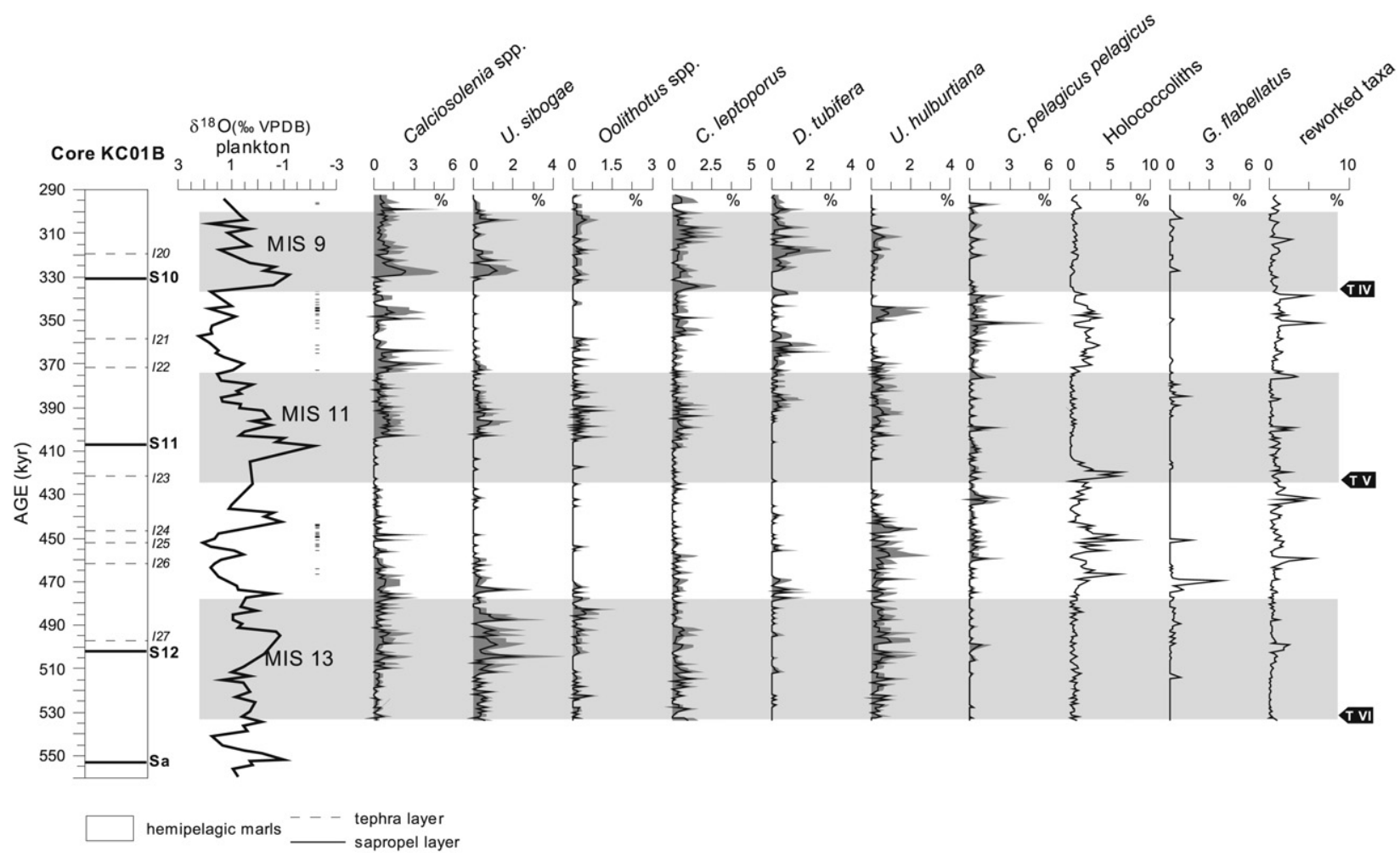

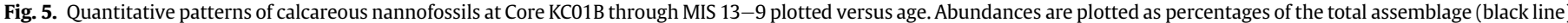

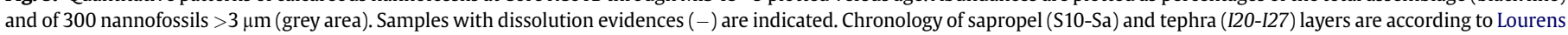
(2004). Grey bands indicate interglacial intervals and are traced according to marine isotope chronology of Lisiecki and Raymo (2005). 

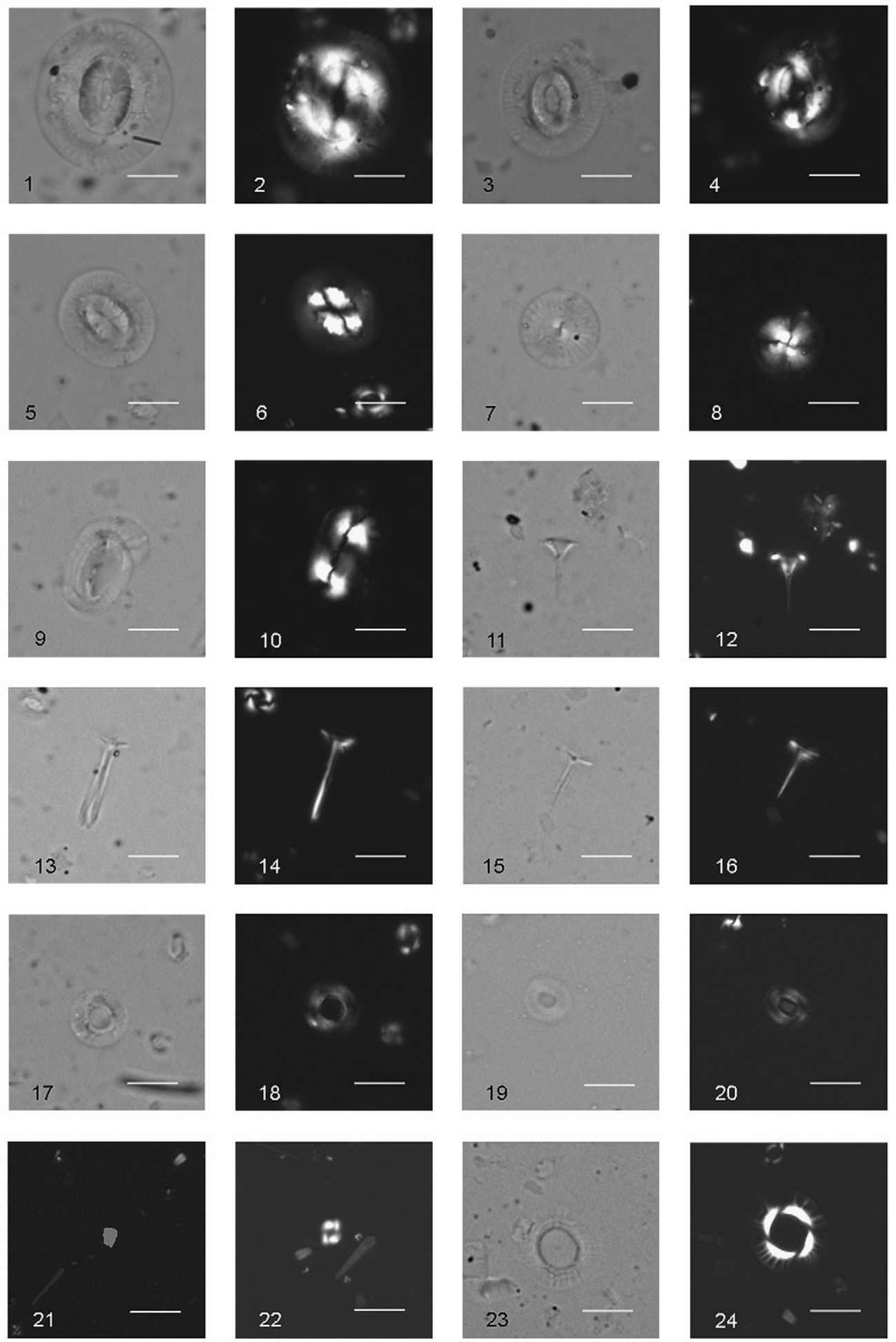

Fig. 6. Light microscope photographs of selected calcareous nannofossil species. PL-parallel light, XP-crossed polarized light. Scale bar represents 5 um. 1-2: Coccolithus pelagicus azorinus Parente and Cachão, in Parente et al., 2004. KC01B, 1696,64 cm; 1, PL; 2, XP. 3-4: Coccolithus pelagicus braarudii (Gaarder, 1962) Geisen et al., 2002. KC01B, 1696,64 cm; 3, PL; 4, XP. 5-6: Coccolithus pelagicus pelagicus (Wallich, 1877) Schiller, 1930. KC01B, 1696,64 cm; 5, PL; 6, XP. 7-8: Calcidiscus leptoporus (Murray and Blackman, 1898) Loeblich and Tappan, 1978. KC01B, 2099 cm; 7, PL; 8, XP. 9-10: Helicosphaera carteri (Wallich, 1877) Kamptner, 1954. KC01B, 1696,64 cm; 9, PL; 10, XP. 11-12: Discosphaera tubifera (Murray and Blackman, 1898) Ostenfeld, 1900. KC01B, 2099 cm; 11, PL; 12, XP. 13-14: Rhabdosphaera clavigera Murray and Blackman, 1898. KC01B, 2099 cm; 13, PL; 14, XP. 15-16: Rhabdosphaera clavigera var. stylifera (Lohmann, 1902) Kleijne and Jordan, 1990. KC01B, 2099 cm; 15, PL; 16, XP. 17-18: Umbilicosphaera sibogae (Weber-van Bosse, 1901) Gaarder, 1970. KC01B, 2099 cm; 17, PL; 18, XP. 19-20: Umbilicosphaera hulburtiana Gaarder, 1970. KC01B, 2099 cm; 19, PL; 20, XP. 21: Florisphaera profunda Okada and Honjo, 1973. KC01B, 2099 cm; XP. 22: Gladiolithus flabellatus (Halldal and Markali, 1955) Jordan and Chamberlain, 1993. KC01B, 2099 cm; XP. 23-24: Pseudoemiliania lacunosa (Kamptner, 1963) Gartner, 1969. KC01B, 2099 cm; 23, PL; 24, XP. 

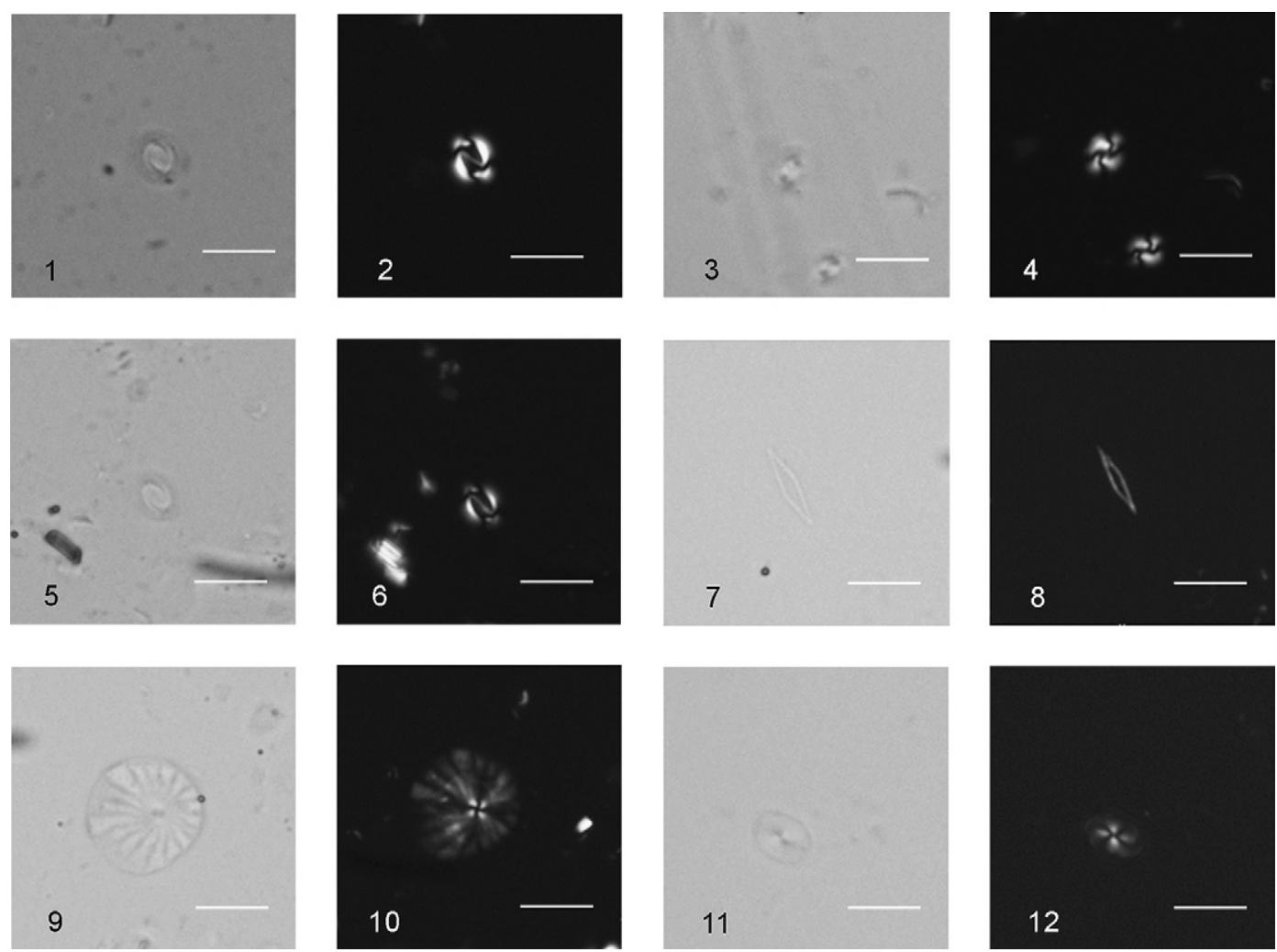

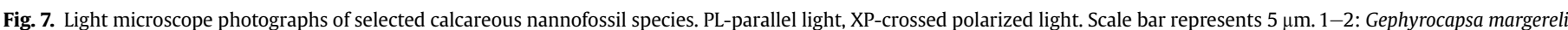

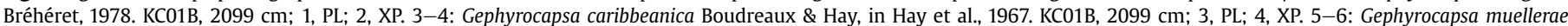

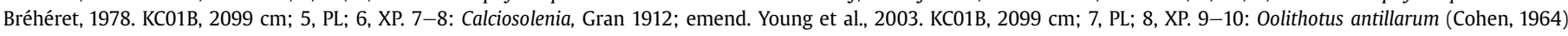
Reinhardt, in Cohen and Reinhardt 1968. KC01B, 1614,5 cm; 9, PL; 10, XP. 11-12: Syracosphaera pulchra Lohmann, 1902. KC01B, 1614,5 cm; 11, PL; 12, XP.

Mediterranean (Incarbona et al., 2009) and in the Atlantic (Flores et al., 2003) not before MIS 6. Reticulofenestra spp. are recorded as common taxa in the assemblages with abundances generally ranging between 10 and 20\%. Increases in abundance are mainly recorded during intervals of glacial phases. Syracosphaera spp. (Syracosphaera histrica and Syracosphaera pulchra) and Rhabdosphaera spp. (Rhabdosphaera clavigera and Rhabdosphaera stylifera) are commonly recorded throughout the studied interval and constitute nearly 5\% and less than $5 \%$ of the assemblage, respectively (Fig. 4). Syracosphaera spp. and Rhabdosphaera spp. have comparable abundance patterns and generally increase during glacial intervals. Helicosphaera carteri, having abundances generally lower than $5 \%$, has a distinct increase at the lower part of MIS 11 and at the MIS 10-9 transition, reaching abundance of about $10 \%$ (Fig. 4). Taxa with subordinate abundances (often $<3 \%$ ) are Calciosolenia spp., Umbilicosphaera sibogae (U. sibogae sibogae and U. sibogae foliosa), Oolithotus spp. (Oolithotus antillarum, Oolithotus fragilis), Calcidiscus leptoporus, Discosphaera tubifera, Umbilicosphaera hulburtiana, Coccolithus pelagicus pelagicus, Holococcoliths, G. flabellatus (Fig. 5). Trends in the abundance patterns of Calciosolenia spp., U. sibogae, Oolithotus spp., on the whole, are quite comparable and exhibit higher abundances during interglacials: particularly, these taxa become very rare or absent during the lower part of MIS 11 (Fig. 5). Holococcoliths, although generally rare in the assemblages, present distinct higher abundances during glacials, as also noted in the distribution patterns of Syracosphaera spp. and Rhabdosphaera spp. Specimens with abundances often $<1 \%$ and only sporadically encountered have not been plotted, and are represented by $C$. leptoporus small type $(3-5 \mu \mathrm{m})$, Calcidiscus quadriperforatus $(8-10 \mu \mathrm{m}), C$. pelagicus braarudii $(10-13 \mu \mathrm{m}), C$. pelagicus azorinus $(14-16 \mu \mathrm{m})$ (Fig. 6), Ceratolithus spp., various helicoliths other than H. carteri (Helicosphaera hyalina, Helicosphaera pavimentum, Helicosphaera wallichii), Gephyrocapsa oceanica, Neosphaera coccolithomorpha, Pontosphaera spp., Scyphosphaera spp., and Umbellosphaera spp. Extinct taxa, mainly consisting of Cretaceous-Paleogene species, occur all through the studied interval. Their abundances are considered an estimation of reworking, generally representing less than $1 \%$ of the assemblage, although occasionally reaching about 5\% (Fig. 5). Reworking peaks seem to match abundance patterns of $C$. pelagicus pelagicus, which may suggest a relation of the taxon with reworking process possibly due to the robustness of this species.

The Shannon-Weaver Index reveals that in Core KC01B the pattern of diversity exhibits several short-term fluctuations, commonly varying between 2 and 1.8 (Fig. 8). However, in distinct intervals, more pronounced shifts are observed with clear decreasing trends occurring in the lowermost part of MIS 13-11, reaching minimum values of $1.2-1.5$.

\section{Discussion}

The composition of calcareous nannofossil assemblage recognized in Core KC01B, with special regards to the most abundant species, appears well comparable to that recorded in surface sediments of the Ionian Sea from Knappertsbusch (1993), who recorded Emiliania huxleyi as the dominant taxon followed, in terms of abundance, by $F$. profunda. E. huxleyi, the modern representative of the family Noelaerhabdaceae, whose first occurrence is dated at $0.265 \mathrm{Ma}$ (Raffi et al., 2006), does not occur in the studied interval. On the other hand, the assemblage is largely dominated by the related middle Pleistocene species belonging to the family Noelaerhabdaceae and 
particularly by small- and medium-sized gephyrocapsids. F. profunda is also a common taxon in the identified assemblage. Among gephyrocapsids, the very low abundance of $G$. oceanica at Core KC01B is in accordance with the smaller proportions of this taxon in surface sediments and waters of the Eastern Mediterranean than in the western basin (Knappertsbusch, 1993; Malinverno et al., 2003). Frequent occurrences of Syracosphaeraceae and Rhabdosphaeraceae, although never abundant, rare occurrences of $C$. pelagicus pelagicus, $H$. carteri and $C$. leptoporus and quite subordinate abundance of delicate taxa such as Calciosiolenia spp., Oolithotus spp., and U. sibogae appear also as a feature of the coccolith assemblage of the Ionian surface sediments and waters. Therefore, the recognized assemblage can be valuable for reconstructing surface water features at time of sediment deposition through MIS 13-9. With respect to previous results on the fossil assemblages from coeval intervals, the considerable abundance of $G$. caribbeanica and of $G$. margereli/muellerae is highly consistent with the global dominance of "Gephyrocapsa Oligotrophic" and of "Gephyrocapsa Transitional" during MIS 13-9 (Bollmann et al., 1998). On the other hand, the distribution through time of several taxa in Core KC01B appears rather complex, probably as the result of peculiar local conditions of surface waters during glacial-interglacial phases. For instance, abundance fluctuations of Syracosphaera spp., Rhabdosphaera spp., Calciosolenia spp., Oolithotus spp., $U$. sibogae, in spite of their common preference for warm and oligotrophic surface waters (Winter et al., 1994; Ziveri et al., 1995, 2004; Baumann et al., 2004; Boeckel and Baumann, 2004; SaavedraPellitero et al., 2010), display a rather divergent quantitative behaviour (Figs. 4 and 5). Among these taxa, the increase in abundance of Syracosphaera spp. and Rhabdosphaera spp. observed during glacial stages appears unusual.

\subsection{Primary productivity proxies}

In order to make more clear the relationship between coccolithophorids and paleoenvironmental conditions at the studied core, a multivariate statistical analyses, by means of Principal Component Analysis (PCA), has been performed using percentages in abundance of taxa as variables in the input matrix. Only the 1 st component, which explains $29.1 \%$ of the total variance, has been considered, as the 2nd component is of rather doubtful interpretation due to the very low variance (15.3\%). The 1 st component (Table 2 ) group, together $G$. caribbeanica and small placoliths with high negative component loadings, and F. profunda, Syracosphaera spp. and Rhabdosphaera spp. with high positive component loadings.

The ecological preferences of G. caribbeanica are not very well established. Bollmann (1997), who includes G. caribbeanica in the

Table 2

Loadings of calcareous nannofossil taxa on the first principal component at Core KC01B. The most relevant component loadings are indicated in bold.

\begin{tabular}{lr}
\hline Taxa & Factor 1 \\
\hline Calciosolenia spp. & 0.460 \\
Discosphaera tubifera & 0.603 \\
Gephyrocapsa caribbeanica & $\mathbf{0 . 8 0 9}$ \\
Gephyrocapsa margereli/muellerae & 0.403 \\
Helicosphaera carteri & 0.011 \\
Reticulofenestra spp. & 0.360 \\
small placoliths & $-\mathbf{0 . 4 2 4}$ \\
Florisphaera profunda & $\mathbf{0 . 7 4 8}$ \\
Holococcoliths & 0.422 \\
Syracosphaera spp. & $\mathbf{0 . 8 2 7}$ \\
Rhabdosphaera spp. & $\mathbf{0 . 6 5 4}$ \\
Umbilicosphaera sibogae & -0.114 \\
Oolithotus spp. & 0.024 \\
C. leptoporus (5-8 $\mu$ m) & -0.043 \\
\hline
\end{tabular}

Method: Principal Component Analysis.
"Gephyrocapsa Oligotrophic" morphotype, indicates for the taxon a preference for warm and oligotrophic conditions. According to more recent literature (Bollmann et al., 1998; Flores et al., 1999; Baumann and Freitag, 2004; Baumann et al., 2004; López-Otálvaro et al., 2008), the heavily calcified G. caribbeanica is considered as the most important producer of carbonate content through MIS 14-8. Furthermore, López-Otálvaro et al. (2008) suggest that the increases in abundance of $G$. caribbeanica can be considered a proxy of high paleoproductivity. In Core $\mathrm{KC} 01 \mathrm{~B}$, the positive correlation between $G$. caribbeanica and small placoliths and negative correlation with $F$. profunda, Syracosphaera spp. and Rhabdosphaera spp. seems to support this last hypothesis. It is well known that small placoliths, which inhabit the upper photic zone, can be considered a proxy of upwelling intensity (Gartner, 1988; Okada and Wells, 1997; Takahashi and Okada, 2000) or of high productivity conditions of surface waters (Gartner et al., 1987; Gartner, 1988; Takahashi and Okada, 2000; Colmenero-Hidalgo et al., 2004; Flores et al., 2005). On the other hand, the negative relationship between abundances of the deep dwelling taxon $F$. profunda and primary productivity of surface water and intensity of upwelling is documented (e.g. Beaufort et al., 1997, 2001; Jordan et al., 1996; Ziveri and Thunell, 2000). The taxon benefits from seasonal stratification, lower surface water productivity and a deep nutricline (Molfino and McIntyre, 1990a, b; McIntyre and Molfino, 1996; Beaufort et al., 1997; Henriksson, 2000). Syracosphaera spp. and Rhabdosphaera spp., which, together with F. profunda, are the main species contributing positively to factor 1 (Table 2), and also have affinities for nutrient depleted and stratified surface waters. Consequently, it is reasonable to assume that the 1 st component is indicative of productivity and/or mixing in surface waters. If this is the case, the factor 1 score plot through time (Fig. 8) suggests more productive/mixed surface waters during the early part of MIS 11 and MIS 9. The fluctuations of diversity strongly parallel the pattern of productivity (Fig. 8) as a response of r-selected species behaviour during more productive surface water conditions (Young, 1994; Bown et al., 2004). In addition, the pattern of factor 1 is well comparable with the profile of the $\mathrm{N}$ index, a valuable paleoproductivity proxy as shown by several studies which used F. profunda in the paleoproductivity ratio (Beaufort et al., 1997, 2001; Flores et al., 2000a; Colmenero-Hidalgo et al., 2004; Maiorano et al., 2009). In particular, it shows higher values during MIS 13 and in the early part of MIS 11 and MIS 9 when the occurrence of a shallow nutricline/thermocline position can be inferred. The coccolithophores are among the most important primary producers of the ocean, and their present-day production in the Ionian Sea is generally known to be higher in autumn-winter (Rabitti et al., 1994; Malinverno et al., 2003), thus reflecting the general seasonal trophic regime of the area. On the other hand, significant variability is known from sedimentary records, which highlight discrepancies with the general cold/high productive and warm/low productive system. Some examples come from the Western Mediterranean, where increases in primary productivity have been recorded in the Alboran Sea during the warm interstadials of the last glacial period and the Holocene (Colmenero-Hidalgo et al., 2004; Moreno et al., 2005) related to an increased gyre-induced upwelling. Furthermore, in the Balearic Basin the highest coccolith concentration is recorded during warm interglacials of the last $100 \mathrm{ka}$ (Flores et al., 1997) as a result of the intensification in the Atlantic water influx and Catalonia-Balearic frontal system. Anomalous decreases in productivity during late Pleistocene cooling events are recorded in the central Mediterranean (Incarbona et al., 2008).

The trend of productivity as inferred in Core KC01B seems to support a complex climate-productivity dynamic possibly influenced by hydrodynamic variability in the Ionian Basin. Taking into consideration the core site (Fig. 1) located near the periphery of the present-day Ionian Anticyclonic gyre, it is possible to hypothesise 
that the increased productivity during interglacials may reflect a local response to a strengthen Atlantic Ionian Stream and related dynamic activity of mesoscale features (meanders and eddies). These features may have perturbed surface water stratification, favouring nutrient supply and primary production at the core location. As observed in several areas of the Mediterranean Sea, the variability in mesoscale hydrographic features such as eddies may locally influence biological productivity (e.g. Estrada, 1996; Morán et al., 2001; Christaki et al., 2011). Increases in coccolithophores productivity are also documented in the western basin during interglacial periods of the Late Pleistocene and related to the instability of the incoming jet of Atlantic water (Flores et al., 1997; Colmenero-Hidalgo et al., 2004).

The distinct productivity pattern at the early MIS 11 and MIS 9 deserves further attention. The productivity increases are also accompanied by intervals of increased abundance of $H$. carteri (Fig. 8), which is well consistent with moderately elevated nutrient surface water conditions (Ziveri et al., 1995, 2000; Andruleit and Rogalla, 2002; Findlay and Giraudeau, 2002; Ziveri et al., 2004). Peaks of $H$. carteri are also reported at terminations through MIS 1-14 in the Southern Ocean (Flores et al., 2003). In addition, it is noteworthy that in the Mediterranean Sea, the increases of H. carteri, which has been observed during Heinrich events, have been also related to fresher and more turbid upper layer (Colmenero-Hidalgo et al., 2004). Therefore, higher fresh water discharge due to enhanced local river runoff may have also played an important role at the core location at the early part of MIS 11 and 9.

\subsection{Warm-water proxies}

As discussed above, according to several authors Syracosphaera spp., Rhabdosphaera spp., Calciosolenia spp., Oolithotus spp., U. sibogae, share a common ecological preference for warm and oligotrophic surface waters. However, in the studied core the patterns of
Syracosphaera spp. and Rhabdosphaera spp. are primarily linked to variation in productivity rather than temperature. On the other hand, it is interesting to note that Calciosolenia spp., Oolithotus spp. and $U$. sibogae, although they never reach a dominant role in the assemblage, display a positive relation with interglacial stages (Fig. 5). The abundance fluctuations of the cumulative curve of these taxa mostly parallel planktonic $\delta^{18} \mathrm{O}$ shifts (Fig. 8), showing higher abundances in the lighter values of the marine isotope record. In addition, they are in very good agreement with the pattern of the climate curve based on planktonic foraminifera assemblage (Lirer et al., 2011; Lirer et al., in prep.). Correlation between calcareous nannofossils and planktonic foraminifera has been presented elsewhere (Tarantino et al., 2011). This suggests that quantitative distribution of Calciosolenia spp., Oolithotus spp. and U. sibogae can be considered as "warm-water" proxies. Several short-term variations are recorded in their abundance patterns (Fig. 8) which point to a high climate variability in the investigated interval both in glacial and interglacial stages. However, the unambiguous correlation with the marine isotope record is temporarily and drastically interrupted across the upper part of MIS 12 (starting from interstadial 12.3) and the lower part of MIS 11, from 448 to $404 \mathrm{ka}$. The rarity of Calciosolenia spp., Oolithotus spp. and U. sibogae at MIS 12-11 can be considered as a primary ecological response of the nannofossil assemblage rather than a dissolution effect, as it is uncorrelated with the dissolution intervals recognized in the core (Fig. 8). This interval is accompanied by a gradual primary productivity increase, suggesting a modification in both temperature and nutrient content of surface water occurred in this interval. The warm-water taxa are particularly rare in the lower part of MIS 11, with the increase of $H$. carteri. Their abundance fluctuations display a restored sharp increase almost coeval to the deposition of sapropel S11 dated at $407 \mathrm{ka}$ (Lourens, 2004), with maximum values from $403 \mathrm{ka}$ to $389 \mathrm{ka}$, during a period of low insolation forcing. This interval can be considered as an indication of a climate optimum interval during

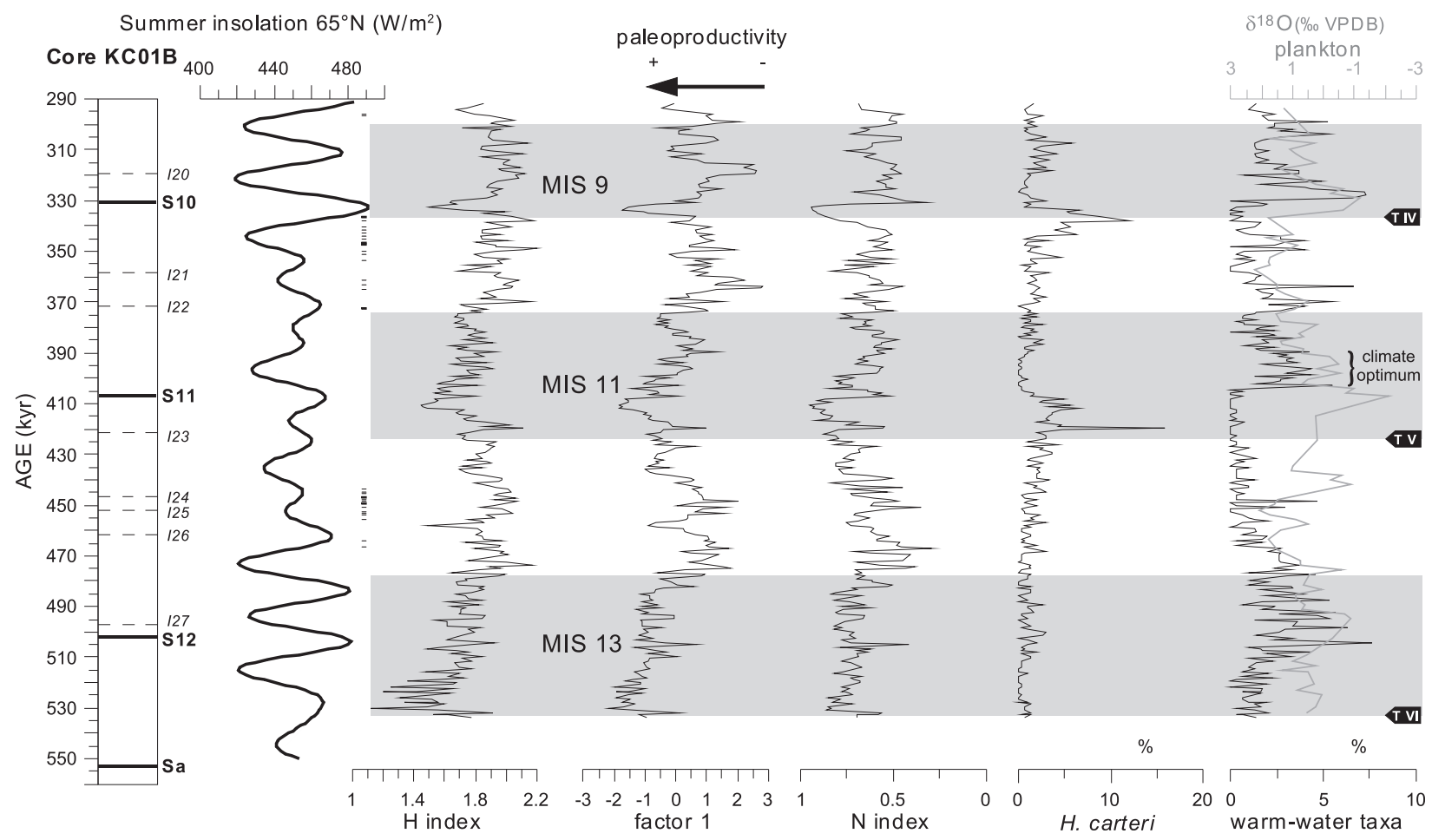

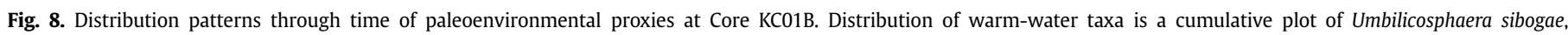

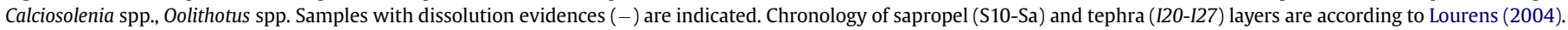

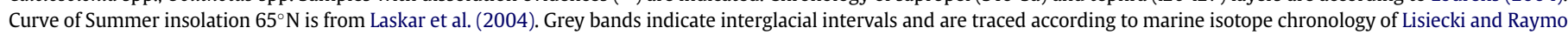
(2005). 
MIS 11, as also confirmed by planktonic foraminifera data (Tarantino et al., 2011). Therefore, a late establishment of warm surface water conditions with respect to Termination V (dated at $424 \mathrm{ka}$, Lisiecki and Raymo, 2005), can be inferred at the core location. The upward gradual decrease of warm-water taxa indicate that a cooling trend developed in the upper part of MIS 11. These data sustain the hypothesis that MIS 11 is a complex interglacial in the eastern Mediterranean (Numberger et al., 2010) as well as in the oceans (Bauch et al., 2000).

\subsection{Paleoclimate evolution during MIS 11}

The calcareous nannofossil data suggest that MIS 11 at Core KC01B is characterized by three distinctive phases (Fig. 9). During the lowermost part, a trend towards increased productivity/shallow nutricline/thermocline position during a period of cool surface waters was promoted, as indicated by the minimum values of $\mathrm{H}$ index and factor 1 and higher values of $\mathrm{N}$ index (Fig. 8). This is more evident mainly between 408 and 416 ka when more productive environment led to the increase of few high-productive taxa (i.e. small placoliths and G. caribbeanica). Low salinity and probably turbid upper layer induced by higher fresh water input can be also invoked in the same interval based on the increase of H. carteri (Fig. 9). A climate optimum then occurred from 403 to $389 \mathrm{ka}$ in the middle part of MIS 11 and correlated with the lowest insolation forcing during MIS 11, centred at 398 ka. Finally, surface water cooling characterized the latest part of MIS 11. Pattern of surface water temperature changes, as deduced by calcareous nannofossils through MIS 11 at Core KC01B, is sustained by evidences from different Atlantic ocean records from high to low latitudes (Oppo et al., 1998; Bauch et al., 2000; Bauch and Erlenkeuser, 2003; Kandiano and Bauch, 2007; Helmke et al., 2008) which indicate that full interglacial conditions, during MIS 11 , became established only after a prolonged deglacial termination which extended into MIS 11 . The climate evolution recorded in Core KC01B was compared with selected deep-sea Atlantic records as reference cores for low to high latitudes (Figs. 1 and 9). Full interglacial-like conditions are recorded at high-latitude records (Core PS1243) not before than 408 ka (Bauch et al., 2000) (Fig. 9) and the beginning of climate optimum in surface waters (Fig. 9) is documented, at mid- and low-latitude records (Core M23414, Site 958), at 402 ka and 409 ka respectively and correlated with the lowest insolation (Fig. 9) (Kandiano and Bauch, 2007; Helmke et al.,
2008), as also observed in Core KC01B. The large ice sheet extension related to the extreme MIS 12 glaciation may be a possible explanation for the late MIS 11 interglacial inception (Kandiano and Bauch, 2007). A more complex framework should be taken into account for the landlocked Mediterranean Sea. In this sense, the climate conditions deduced from the low latitude Atlantic Site 958, located off NW Africa (Helmke et al., 2008), are relevant for the Mediterranean. In this record, a minimum in the aeolian dust input suggests that a pronounced wet phase had occurred between about 420 and $409 \mathrm{ka}$, during the early MIS 11 (Fig. 9) and prior to the insolation maximum (Helmke et al., 2008). Enhanced activity of the monsoon system on the Saharan-Sahel region and related reduction in trade wind intensity off NW Africa are assumed to be responsible for the enhanced wet conditions/higher runoff from the African continent, leading to increased fresh water input into the Mediterranean Sea and to deposition of sapropel S11 (Helmke et al., 2008). The results at Core KC01B offer mid-latitude Mediterranean evidence which is highly consistent with this scenario. Despite possible uncertainties in comparing different age models, the interval of productive, low salinity and turbid waters at Core KC01B is very well comparable with the timing of the wet phase (420-409 ky) recorded at Site 958 (Fig. 9) and could be the result of the increased monsoonal precipitation which ensured higher fresh water input into the Eastern Mediterranean Basin. The fresh water input into the basin seems to culminate with the deposition of sapropel S11 as indicated by the markedly lower $\delta^{18} \mathrm{O}$ values (Fig. 9). Enhanced productivity in surface waters at Core KC01B in the lower part of MIS 11 may have been sustained by increased delivery of land-derived nutrients or even shoaling of the nutricline due to low salinity surface water lens as invoked for Eastern Mediterranean sapropel deposition (e.g. Rohling and Gieskes, 1989; Rohling, 1991; Rohling and Hilgen, 1991; Castradori, 1993). The identification of a fresh water source at the core location is beyond the focus of the present paper. However, it is known that monsoon fluvial discharge affected the Eastern Mediterranean, not only through the traditional Nile River route, but along wider tracts of the North African margin (Rohling et al., 2002), depending on the penetration of the Intertropical Convergence Zone over the African continent. In this framework, it is interesting to highlight that chronology of North Saharan palaeolake records in the present-day Libyan desert provides good correlation with MIS 11 (Thiedig et al., 2000; Armitage et al., 2007). This gives further evidence for continental humidity over North African in this

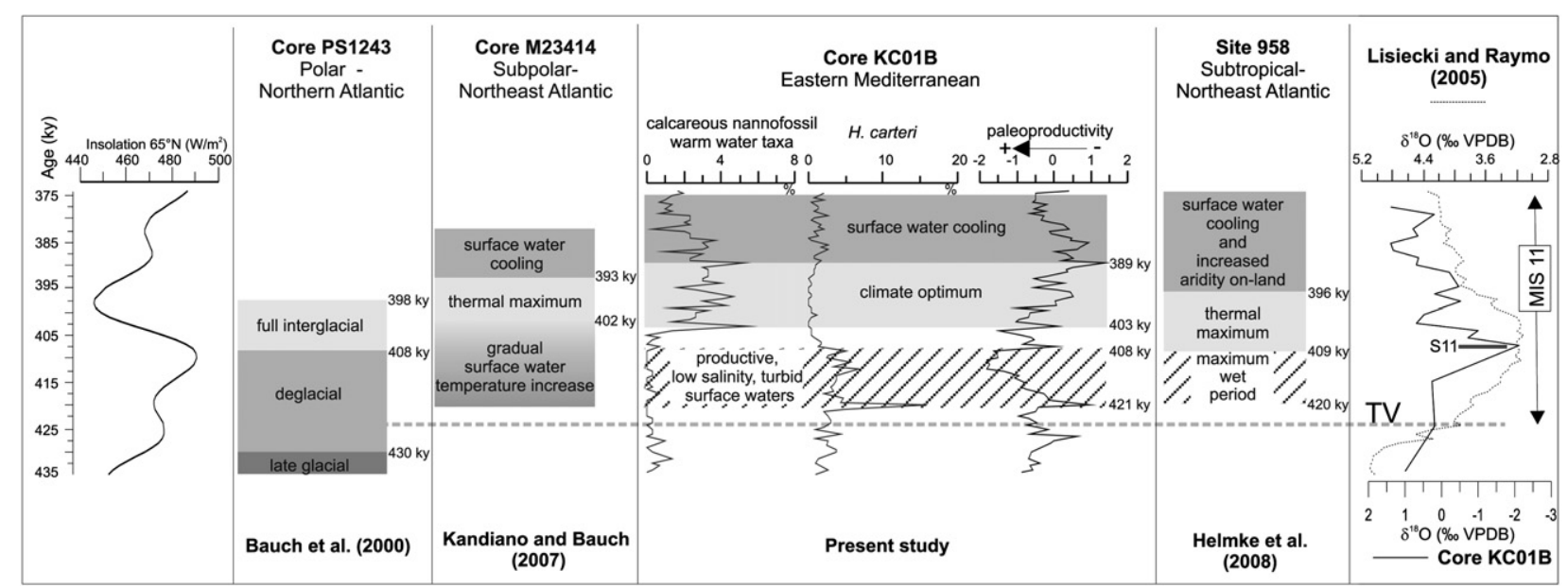

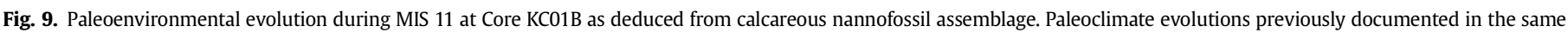

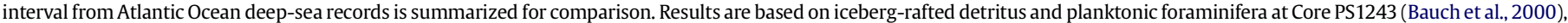

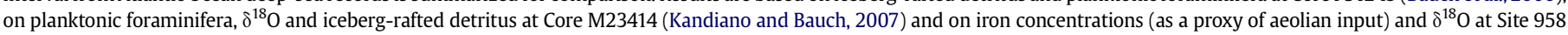
(Helmke et al., 2008). Summer insolation $65^{\circ} \mathrm{N}$ from Laskar et al. (2004). 
period, suggesting a possible source area for the fresh water flux into the Ionian Sea.

At the same time, the wet-climate conditions developed in North Africa and the increased fluvial discharge affected surface water features in the Eastern Mediterranean during the lower part of MIS 11, gradual Sea Surface Temperature increases occurred at subpolar locations (Kandiano and Bauch, 2007), and a long-lasting deglacial phase affected the high-northern Atlantic (Bauch et al., 2000). The subsequent development of climate optimum in the middle part of MIS 11 is comparable with the timing of the icebergrafted detritus-free interval and expansion of warm water advection into the polar North as recorded at Core PS1243 (full interglacial in Fig. 9) and with the thermal ocean maxima documented by means of faunal and $\delta^{18} \mathrm{O}$ changes at mid- and low-latitudes (Fig. 9). Finally, widespread climate deterioration seems to characterize the later part of MIS 11, as recorded at different latitudes (Fig. 9).

\section{Conclusion}

A quantitative study based on calcareous nannofossil assemblage was carried out on Core KC01B from the Ionian Basin. Distribution patterns of taxa were compared to the available oxygen isotope record through MIS 13-9, between 500 and $300 \mathrm{ka}$, and were used to reconstruct surface water conditions. The results indicate that the composition of calcareous nannofossil assemblage is the result of the interplay between climate variability and peculiar features of Ionian surface water circulation. The high abundance of $G$. caribbeanica and G. margereli/muellerae provides evidence of the global dominance of Gephyrocapsa in the Mediterranean during the Mid-Brunhes event. The distribution of G. caribbeanica, small placoliths, F. profunda, Syracosphaera spp. and Rhabdosphaera spp. suggests that primary productivity and stratification of surface waters represent the principal features affecting calcareous nannofossil assemblage. Higher primary productivity, coupled with lower diversity of nannofossil assemblage, is observed during interglacial MIS 13 and in the lower part of MIS 11 and MIS 9. Increases in primary productivity during interglacials are possibly induced by variability in AIS intensity and activity of mesoscale hydrographic features into the basin that may have affected stability and nutrient content of surface waters. Distribution of Calciosolenia spp., U. sibogae, and Oolithotus spp. appears as a valuable tool for reconstructing surface water temperature variations in the studied area, and highlights significant climate variability at the core location. The climate evolution of MIS 11 was inferred in the studied core and compared with other Atlantic reference records. The early MIS 11 (421-408 ka) is characterized by increasing productivity, low salinity and turbid waters and is coeval with the development of a pronounced humid period over Northwest Africa, which was responsible, through monsoonal precipitation, for higher fresh water input/land-derived nutrient into the basin. Warm surface water conditions, which occurred during a period of low insolation forcing, appeared at about $403 \mathrm{ka}$ and lasted for about $15 \mathrm{ky}$. The onset of climate deterioration occurred at about $389 \mathrm{ka}$ and characterized the latter part of MIS 11. The results support the hypothesis that complex paleoenvironmental conditions interacts during MIS 11 at the core location and provide evidence for a close connection between Mediterranean and Atlantic climatic regimes.

\section{Acknowledgments}

The authors wish to thank Alessandro Incarbona for helpful discussion on the taxonomy of a few taxa. The valuable suggestions and critical reviews of two anonymous reviewers are greatly acknowledged. This research was financially supported by
Università di Bari: Fondi di Ateneo, R. La Perna, 2009 and PhD fellowship provided to F. Tarantino.

\section{Appendix. List of taxa cited in the text}

Calcidiscus leptoporus (Murray and Blackman, 1898) Loeblich and Tappan, 1978

Calcidiscus leptoporus "small” (3-5 $\mu \mathrm{m})$ sensu Knappertsbusch et al., 1997

Calcidiscus quadriperforatus (Kamptner, 1937) Quinn et al., 2004 Calciosolenia Gran 1912; emend. Young et al., 2003

Ceratolithus Kamptner, 1950

Coccolithus pelagicus pelagicus (Wallich, 1877) Schiller, 1930

Coccolithus pelagicus braarudii (Gaarder, 1962) Geisen et al., 2002

Coccolithus pelagicus azorinus Parente et al., 2004

Discosphaera tubifera (Murray and Blackman, 1898) Ostenfeld, 1900

Florisphaera profunda Okada and Honjo, 1973

Gephyrocapsa caribbeanica Boudreaux and Hay, in Hay et al., 1967

Gephyrocapsa muellerae Bréhéret, 1978

Gephyrocapsa oceanica Kamptner, 1943

Gephyrocapsa margereli Bréhéret, 1978

Gladiolithus flabellatus (Halldal and Markali, 1955) Jordan and Chamberlain, 1993

Helicosphaera carteri (Wallich, 1877) Kamptner, 1954

Helicosphaera hyalina Gaarder, 1970

Helicosphaera inversa (Gartner, 1977) Theodoridis, 1984

Helicosphaera wallichii (Lohmann, 1902) Okada and McIntrye, 1977

Helicosphaera pavimentum Okada and McIntyre, 1977

Holococcoliths (sensu Young and Bown, 1997)

Neosphaera coccolithomorpha Lecal-Schlauder, 1950

Oolithotus antillarum (Cohen, 1964) Reinhardt, in Cohen and

Reinhardt, 1968

Oolithotus fragilis (Lohmann, 1912) Martini and Müller, 1972

Pontosphaera Lohmann, 1902

Pseudoemiliania lacunosa (Kamptner, 1963) Gartner, 1969

Reticulofenestra Hay, Mohler and Wade, 1966

Rhabdosphaera clavigera Murray and Blackman, 1898

Rhabdosphaera clavigera var. stylifera (Lohmann, 1902) Kleijne and Jordan, 1990

"small placoliti": reticulofenestrids $<3 \mu \mathrm{m}$ and Gephyrocapsa spp. $<3 \mu \mathrm{m}$

Scyphosphaera Lohmann, 1902

Syracosphaera pulchra Lohmann, 1902

Syracosphaera histrica Kamptner, 1941

Umbellosphaera Paasche, in Markali and Paasche, 1955

Umbilicosphaera sibogae (Weber-van Bosse, 1901) Gaarder, 1970

Umbilicosphaera foliosa (Kamptner, 1963; ex Kleijne, 1993)

Geisen, in Sáez et al., 2003

Umbilicosphaera hulburtiana Gaarder, 1970

\section{References}

Allen, J.I., Somerfield, P.J., Siddorn, J., 2002. Primary and bacterial production in the Mediterranean Sea: a modelling study. Journal of Marine Systems 33-34, 473-495. Andruleit, H.A., Rogalla, U., 2002. Coccolithophores in surface sediments of the Arabian Sea in relation to environmental gradients in Surface waters. Marine Geology 186, 505-526.

Armitage, S.J., Drake, N.A., Stokes, S., El-Hawat, A., Salem, M.J., White, K., Turner, P., McLaren, S.J., 2007. Multiple phases of North African humidity recorded in lacustrine sediments from the Fazzan Basin, Libyan Sahara. Quaternary Geochronology 2, 181-186.

Astraldi, M., Balopoulos, S., Candela, J., Font, J., Gačić, M., Gasparini, G.P., Manca, B. Theocaris, A., Tintoré, J., 1999. The role of straits and channels in understanding the characteristics of the Mediterranean circulation. Progress in Oceanography 44, 65-108.

Barker, S., Archer, D., Booth, L., Elderfield, H., Henderiks, J., Rickaby, R.E.M., 2006. Globally increased pelagic carbonate production during the Mid-Bruhnes dissolution interval and the $\mathrm{CO}_{2}$ paradox of MIS 11. Quaternary Science Reviews 25, 3278-3293. 
Bassinot, F.V., Labeyrie, L.D., Vincent, E., Quidelleur, X., Shackleton, N.J., Lancelot, Y., 1994. The astronomical theory of climate and the age of the Brunhes-Matuyama magnetic reversal. Earth and Planetary Sciences Letters 126, 91-108.

Bauch, H.A., Erlenkeuser, H., Helmke, J.P., Struck, U., 2000. A paleoclimatic evaluation of marine oxygen isotope stage 11 in the high Northern Atlantic (Nordic Seas). Global and Planetary Change 24, 27-39.

Bauch, H.A., Erlenkeuser, H., 2003. Interpreting glacial-interglacial changes in ice volume and climate from subarctic deep water foraminiferal $\delta^{18} \mathrm{O}$. In: Droxler, A.W., Poore, R.Z., Burckle, L.H. (Eds.), Earth's Climate and Orbita Eccentricity: The Marine Isotope Stage 11 Question. American Geophysical Union Monograph Series, Washington, DC, pp. 83-102.

Baumann, K.-H., Freitag, T., 2004. Pleistocene fluctuations in the northern Benguela Current system as revealed by coccolith assemblages. Marine Micropaleontology 52, 195-215.

Baumann, K.-H., Bockel, B., Frenz, M., 2004. Coccolith contribution to South Atlantic carbonate sedimentation. In: Thierstein, H.R., Young, J. (Eds.), Coccolithophores from Molecular Processes to Global Impact. Springer, Berlin, pp. 367-402.

Beaufort, L., Lancelot, Y., Camberlin, P., Cayre, O., Vincent, E., Bassinot, F., Labeyrie, L. 1997. Insolation cycles as a major control of Equatorial Indian Ocean primary production. Science 278, 1451-1454.

Beaufort, L., de Garidel-Thoron, T., Mix, A.C., Pisias, N.G., 2001. ENSO-like forcing on oceanic primary production during the late Pleistocene. Science 293, 2440-2444.

Bethoux, J.P., Morin, P., Madec, C., Gentili, B., 1992. Phosphorus and nitrogen behaviour in the Mediterranean Sea. Deep-Sea Research 39, 1641-1654.

Boeckel, B., Baumann, K.-H., 2004. Distribution of coccoliths in surface sediments of the southeastern South Atlantic Ocean: ecology, preservation and carbonate contribution. Marine Micropaleontology 51, 301-320.

Bollmann, J., 1997. Morphology and biogeography of Gephyrocapsa coccoliths in Holocene sediments. Marine Micropaleontology 29, 319-350.

Bollmann, J., Baumann, K.-H., Thierstein, H.R., 1998. Global dominance of Gephyrocapsa coccoliths in the late Pleistocene: selective dissolution, evolution, or global environmental change? Paleoceanography 13, 517-529.

Boucher, K., 1975. Global Climate. The English University Press Ltd., London.

Bowen, D.Q., 2010. Sea level 400000 years ago (MIS 11): analogue for present and future sea-level? Climate of the Past Discussions 5, 1853-1882.

Bown, P.R., Young, J.R., 1998. Chapter 2: techniques. In: Bown, P.R. (Ed.), Calcareous Nannofossil Biostratigraphy. Kluwer Academic Publishing, Dordrecht, pp. 16-28.

Bown, P.R., Lees, J.A., Young, J.R., 2004. Calcareous nannoplankton evolution and diversity through time. In: Thierstein, H.R., Young, J.R. (Eds.), Coccolithophores from Molecular Processes to Global Impact. Springer, Berlin, pp. 482-508.

Brand, L.E., 1994. Physiological ecology of marine coccolithophores. In: Winter, A., Siesser, W. (Eds.), Coccolithophores. Cambridge University Press, Cambridge pp. $39-49$.

Bréhéret, J. 1978. Formes nouvelles quaternaires et actuelles de la famille des Gephyrocapsaceae (Coccolithophorides). Comptes Rendus Hebdomadaires des Séances de l'Academie des Sciences Paris 287, 447-449.

Castradori, D., 1993. Calcareous nannofossil biostratigraphy and biochronology in Eastern Mediterranean deep-sea cores. Rivista Italiana Paleontologia e Stratigrafia 99 (1), 107-126.

Christaki, U., Van Wambeke, F., Lefevre, D., Lagaria, A., Prieur, L., Pujo-Pay, M. Grattepanche, J.-D., Colombet, J., Psarra, S., Dolan, J.R., Sime-Ngando, T., Conan, P., Weinbauer, M.G., Moutin, T., 2011. The impact of anticyclonic mesoscale structures on microbial food webs in the Mediterranean Sea. Biogeosciences Discuss $8,185-220$.

Crispi, G., Crise, A., Mauri, E., 1999. A seasonal three-dimensional study of the nitrogen cycle in the Mediterranean Sea: Part II. Verification of the energy constrained trophic model. Journal of Marine Systems 20, 357-379.

Colmenero-Hidalgo, E., Flores, J.A., Sierro, J., Barcena, M.A., Lowemark, L, Schonfeld, J., Grimalt, J.O., 2004. Ocean surface water response to short-term climate changes revealed by coccolithophores from the Gulf of Cadiz (NE Atlantic) and Alboran Sea (W Mediterranean). Palaeogeography, Palaeoclimatology, Palaeoecology 205, 317-336.

Crowley, T.J., 1985. Late Quaternary carbonate changes in the North Atlantic and Atlantic/Pacific comparisons. In: Sunquist, E.T., Broecker, W.S. (Eds.), The Carbon Cycle and Atmospheric $\mathrm{CO}_{2}$ : Natural Variations, Archaean to Present. American Geophysical Union, pp. 271-284.

de Abreu, L., Abrantes, F., Shackleton, N., Tzedakis, P.C., McManus, J.F., Oppo, D.W. Hall, M.A., 2005. Ocean climate variability in the eastern North Atlantic during interglacial marine isotope stage 11: a partial analogue for the Holocene? Paleoceanography 20, PA3009. doi:10.1029/2004PA001091, 2005.

Droxler, A.W., Morse, J.W., Kornicker, W.A., 1988. Controls on carbonate minera accumulation in Bahamian basins and adjacent Atlantic Ocean sediments Journal of Sedimentary Research 58, 120-130.

Droxler, A.W., Ferro, E.C., Mucciarone, D.A., Haddad, G.A., 1997. The marine carbonate system during oxygen isotope stage 11 (423-362 ka): a case of basinto-shelf and/or basin-to-basin carbonate fractionation? EOS, Transaction American Geophysical Union 78, S179.

Droxler, A.W., Farrell, J.W., 2000. Marine isotope stage 11 (MIS 11): new insights for a warm future. Global and Planetary Change 24, 1-5.

Droxler, A.W., Alley, R.B., Howard, W.R., Poore, R.Z., Burckle, L.H., 2003. Unique and exceptionally long interglacial Marine isotope stage 11: window into earth warm future climate, main Introduction. In: Droxler, A.W., Poore, R.Z., Burckle, L.H. (Eds.), 2003. Earth's Climate and Orbital Eccentricity: The Marine Isotope Stage 11 Question, vol. 137. American Geophysical Union Monograph Series, Washington, DC, pp. 69-85.
EPICA community members, 2004. Eight glacial cycles from an Antarctic ice core. Nature 429, 623-628.

Estrada, M., 1996. Primary production in the northwestern Mediterranean. Science Marine 60 (Suppl. 2), 55-64

Findlay, C.S., Giraudeau, J., 2002. Movement of oceanic fronts south Australia during the last $10 \mathrm{Ka}$ : interpretation of calcareous nannoplankton in surface sediments from the southern ocean. Marine Micropaleontology 89 (33), 1-14.

Flores, J.A., Sierro, F.J., Francés, G., Vázquez, A., Zamarreño, Y., 1997. The last 100,000 years in the western Mediterranean sea surface water and frontal dynamics as revealed by coccolithophores. Marine Micropaleontology 29, 351-366.

Flores, J.A., Gersonde, R., Sierro, F.J., 1999. Pleistocene fluctuations in the Agulhas Current retroflection based on the calcareous plankton record. Marine Micropaleontology 37, 1-22.

Flores, J.-A., Bárcena, M.A., Sierro, F.J., 2000a. Ocean-surface and wind dynamics in the Atlantic Ocean off Northwest Africa during the last 140,000 years. Palaeogeography, Palaeoclimatology, Palaeoecology 161, 459-478.

Flores, J.A., Gersonde, R., Sierro, F.J., Niebler, H.S., 2000b. Southern Ocean Pleistocene calcareous nannofossil events: calibration with isotope and geomagnetic stratigraphies. Marine Micropaleontology 40, 377-402.

Flores, J.A., Marino, M., Sierro, F.J., Hodell, D.A., Charles, C.D., 2003. Calcareous plankton dissolution pattern and coccolithophore assemblages during the last $600 \mathrm{ka}$ at ODP Site 1089 (Cape Basin, South Atlantic): paleoceanographic implications. Palaeogeography, Palaeoclimatology, Palaeoecology 196, 409-426.

Flores, J.A., Sierro, F.J., Filippelli, G.M., Bárcena, M.Á., Pérez-Folgado, M., Vázquez, A. Utrlilla, R., 2005. Surface water dynamics and phytoplankton communities during deposition of cyclic late Messinian sapropel sequences in the western Mediterranean. Marine Micropaleontology 56, 50-79.

Fusco, G., Manzella, G.M.R., Cruzado, A., Gacic, M., Gasparini, G.P., Kovacevic, V., Millot, C., Tziavos, C., Velasquez, Z.R., Walne, A., Zervakis, V., Zodiatis, G., 2003. Variability of mesoscale features in the Mediterranean Sea from XBT data analysis. Annales Geophysicae 21, 21-32.

Gartner, S., 1988. Paleoceanography of the Mid-Pleistocene. Marine Micropaleontology $13,23-46$.

Gartner, S., Chow, J., Stanton, R.J., 1987. Late Neogene paleoceanography of the eastern Caribbean, the Gulf of Mexico, and the eastern Equatorial Pacific. Marine Micropaleontology 12 (3), 255-304.

Hammer, Ø., Harper, D.A.T., Ryan, P.D., 2001. PAST: Paleontological statistics software package for education and data analysis. Palaeontologia Electronica 4 (1), 9

Hearty, P.J., Kindler, P., Cheng, H., Edwards, R.L., 1999. A +20 m middle Pleistocene sea-level highstand (Bermuda and the Bahamas) due to partial collapse of Antarctic ice. Geology 27, 375-378.

Helmke, J.P., Bauch, H.A., 2003. Comparison of glacial and interglacial conditions between the polar and the subpolar North Atlantic Region over the past five climate cycles. Paleoceanography 18 (2), 1036. doi:10.1029/2002PA000794.

Helmke, J.P., Bauch, H.A., Röhl, U., Kandiano, E.S., 2008. Uniform climate development between the subtropical and subpolar Northeast Atlantic across marine isotope stage 11. Climate of the Past Discussions 4, 433-457.

Henriksson, A.S., 2000. Coccolithophore response to oceanographic changes in the equatorial Atlantic during the last 200,000 years. Palaeogeography, Palaeoclimatology, Palaeoecology 156, 161-173.

Hine, N., Weaver, P.P.E., 1998. Quaternary. In: Bown, P.R. (Ed.), Calcareous Nannofossil Biostratigraphy. Kluwer Academic Publishing, Dordrecht, pp. 266-283.

Hodell, D.A., Charles, C.D., Ninneman, U.S., 2000. Comparison of interglacial stages in the South Atlantic sector of the southern ocean for the past $450 \mathrm{ka}$ : implications for marine isotope stage (MIS) 11. Global and Planetary Change 24 (1), 7-26.

Howard, W.R., 1997. A warm future in the past. Nature 388, 418-419.

Howard, W.R., Prell, W.L., 1994. Late Quaternary Southern Ocean carbon cycling data: implications for oceanic and atmospheric carbon cycling. Paleoceanography $9,453-482$.

Incarbona, A., Bonomo, S., Di Stefano, E., Zgozi, S., Essarbout, N., Talha, M., Tranchida, G., Bonanno, A., Patti, B., Placenti, F., Buscaino, G., Cuttitta, A., Basilone, G., Bahri, T., Massa, F., Censi, P., Mazzola, S., 2008. Calcareous nannofossil surface sediment assemblages from the Sicily Channel (central Mediterranean Sea): palaeoceanographic implications. Marine Micropaleontology 67, 297-309.

Incarbona, A., Di Stefano, E., Bonomo, S., 2009. Calcareous nannofossil biostratigraphy of the central Mediterranean Basin during the last 430000 years. Stratigraphy $6,33-44$

Jansen, J.H.F., Kuijpers, A., Troelstra, S.R., 1986. A Mid-Brunhes climatic event: long-term changes in global atmospheric and ocean circulation. Science 232 $619-622$.

Jordan, R.W., Zhao, M., Eglinnton, G., Weaver, P.P.E., 1996. Coccolith and alkenone stratigraphy and paleoceanography at an upwelling site off NW Africa (ODP 658C) during the last 130,000 years. In: Moguilevsky, A., Whatley, R. (Eds.), Microfossils and Oceanic Environments. Aberystwyth Press, University of Wales, pp. 111-130.

Jouzel, J., Masson-Delmotte, V., Cattani, O., Dreyfus, G., Falourd, S., Hoffmann, G., Minster, B., Nouet, J., Barnola, J.M., Chappellaz, J., Fischer, H., Gallet, J.C., Johnsen, S., Leuenberger, M., Loulergue, L., Luethi, D., Oerter, H., Parrenin, F., Raisbeck, G., Raynaud, D., Schilt, A., Schwander, J., Selmo, E., Souchez, R. Spahni, R., Stauffer, B., Steffensen, J.P., Stenni, B., Stocker, T.F., Tison, J.L., Werner, M., Wolff, E.W., 2007. Orbital and millennial Antarctic climate variability over the past 800,000 years. Science $317,793-796$

Kandiano, E., Bauch, H., 2007. Phase relationship and surface water mass change in the Northeast Atlantic during marine isotope stage 11 (MIS 11). Quaternary Research 68 (3), 445-455. 
Kindler, P., Hearty, P.J., 2000. Elevated marine terraces from Eleuthera (Bahamas) and Bermuda: sedimentological, petrographic and geochronological evidence for important deglaciation events during the middle Pleistocene. Global and Planetary Change 24, 41-58.

Klein, B., Roether, W., Manca, B.B., Bregant, D., Beitzel, V., Kovacevic, V., Luchetta, A. 1999. The large deep water transient in the eastern Mediterranean. Deep-sea Research I 46, 371-414.

Knappertsbusch, M., 1993. Geographic distribution of living and Holocene coccolithophores in the Mediterranean Sea. Marine Micropaleontology 21, 219-247.

Krom, M.D., Brenner, S., Kress, N., Gordon, L.I., 1991. Phosphorus limitation of primary productivity in the E. Mediterranean Sea. Limnology and Oceanography 36, 424-432.

Krom, M.D., Kress, N., Neori, A., Gordon, L.I., 1992. Nutrient dynamics and new production in a warm-core eddy from the E. Mediterranean. Deep-Sea Research 39, 467-480.

Krom, M.D., Brenner, S., Kress, N., Neori, A., Gordon, I.L., 1993. Nutrient distributions during an annual cycle across a warm-core eddy from the E. Mediterranean Sea. Deep-Sea Research 40, 805-825.

Krom, M.D., Groom, S., Zohary, T., 2003. The Eastern Mediterranean. In: Black, K.D.S.G.B. (Ed.), The Biogeochemistry of Marine Systems. Blackwell, pp. 91-126.

Langereis, C.G., Dekkers, M.J., De Lange, G.J., Paterne, M., Van Santvoort, P.J.M., 1997. Magnetostratigraphy and astronomical calibration of the last 1.1 Myr from an eastern Mediterranean piston core and dating of short events in the Brunhes. Geophysical Journal International 129, 75-94.

Lascaratos, A., Williams, R.G., Tragou, E., 1993. A mixed layer study of the formation of Levantine intermediate water. Journal of Geophysical Research 98 (8), 14739-14749.

Laskar, J., Robutel, P., Joutel, F., Gastineau, M., Correia, A.C.M., Levrard, B., 2004. A Long-term Numerical Solution for the Insolation Quantities of the Earth: Astronomy and Astrophysics, vol. 428, pp. 261-285.

Lermusiaux, P.F.J., Robinson, A.R., 2001. Features of dominant mesoscale variability, circulation patterns and dynamics in the Strait of Sicily. Deep Sea Research I 48, 1953-1997.

Lirer, F., Afferri, A., Bergami, C., Capotondi, L., De Lange, G., Ferraro, L., Foresi, L.M. Girone, A., Lourens, L., Pelosi, N., Vallefuoco, M., Verducci, M., 2011. Variability in the Ionian Sea (Core KC01B) during MIS 9-13 evidenced by planktonic foraminiferal assemblages. Il Quaternario italiano: conoscenze e prospettive. AIQUA Congress, Roma February 2011. Il Quaternario 24, 211.

Lisiecki, L.E., Raymo, M.E., 2005. A Pliocene-Pleistocene stack of 57 globally distributed benthic $\delta^{18} \mathrm{O}$ records. Paleoceanography 20, PA1003.

Lolis, C.J., Bartzokas, A., Katsoulis, B.D., 2002. Spatial and temporal 850 hPa air temperature and sea-surface temperature covariances in the Mediterranean region and their connection to atmospheric circulation. International Journal of Climatology 22, 663-676.

López-Otálvaro, G.E., Flores, J.A., Sierro, F.J., Cacho, I., 2008. Variations in coccolithophorid production in the Eastern Equatorial Pacific at ODP Site 1240 over the last seven glacial-interglacial cycles. Marine Micropaleontology 69, 52-69.

Lourens, L., 2004. Revised tuning of ocean drilling program site 964 and KC01B (Mediterranean) and implications for the $\delta^{18} \mathrm{O}$, tephra, calcareous nannofossil, and geomagnetic reversal chronologies of the past 1.1 Myr. Paleoceanography 19, PA3010.

Loutre, M.F., Berger, A., 2003. Marine isotope stage 11 as an analogue for the present interglacial. Global and Planetary Change 36, 209-217.

Maiorano, P., Marino, M., Flores, J.-A., 2009. The warm interglacial marine isotope stage 31: evidences from the calcareous nannofossil assemblages at Site 1090 (Southern Ocean). Marine Micropaleontology 71, 166-175.

Malanotte-Rizzoli, P., Hecht, A., 1988. Large-scale properties of the Eastern Mediterranean: a review. Oceanologica Acta 11 (4), 323-335.

Malanotte-Rizzoli, P., Bergamasco, A., 1991. The wind and thermally driven circulation of the eastern Mediterranean Sea. Part II: the Baroclinic case. Dynamics of Atmospheres and Oceans 15, 355-419.

Malanotte-Rizzoli, P., Manca, B.B., Ribera d'Alcalà, M., Theocharis, A Bergamasco, A., Bregant, D., Budillon, G., Civitarese, G., Georgopoulos, D., Michelato, A., Sansone, E., Scarazzato, P., Souvermezoglou, E., 1997. A synthesis of the Ionian Sea hydrography, circulation and water mass pathways during POEM-Phase I. Progress in Oceanography 39, 153-204.

Malanotte-Rizzoli, P., Manca, B.B., Ribera d'Alcalà, M., Theocharis, A., Brenner, S., Budillon, G., Ozsoy, E., 1999. The eastern Mediterranean in the 80s and 90s: the big transition in the intermediate and deep circulations. Dynamics of Atmospheres and Oceans 29, 365-395.

Malinverno, E., Ziveri, P., Corselli, C., 2003. Coccolithophorid distribution in the Ionian Sea and its relationship to eastern Mediterranean circulation during late fall to early winter 1997. Journal of Geophysical Research 108 (C9), 8115.

Marino, M., Maiorano, M., Monechi, S., 2003. Quantitative Pleistocene calcareous nannofossil biostratigraphy of Leg 86 Site 577 (Shatsky Rise, Northwestern Pacific Ocean). Journal of Nannoplankton Research 25 (1), 25-37.

Masson-Delmotte, V., Dreyfus, G., Braconnot, P., Johnsen, S., Jouzel, J., Kageyama, M., Landais, A., Loutre, M.F., Nouet, J., Parrenin, F., Raynaud, D., Stenni, B., Tuenter, E., 2006. Past temperature reconstructions from deep ice cores: relevance for future climate change. Climate of the Past 2, 145-165.

Matsuoka, H., Okada, H., 1989. Quantitative analysis of Pleistocene nannoplankton in the subtropical northwestern Pacific Ocean. Marine Micropaleontology 14 97-118.

McIntyre, A., Bè, A.H.W., 1967. Modern coccolithophores of the Atlantic Ocean- I. Placolith and cyrtoliths. Deep-Sea Research 14, 561-597.
McIntyre, A., Molfino, B., 1996. Forcing of Atlantic equatorial and subpolar millennial cycles by precession. Science $274,1867-1870$.

McManus, J., Oppo, D., Cullen, J., Healey, S., 2003. marine isotope stage 11 (MIS 11): analog for Holocene and future climate?. In: Droxler, A.W., Poore, R.Z., Burckle, L.H. (Eds.), 2003. Earth's Climate and Orbital Eccentricity: The Marine Isotope Stage 11 Question, vol. 137 American Geophysical Union Monograph Series, Washington, DC, pp. 69-85.

Molcard, A., Pinardi, N., Iskandarani, M., Haidvogel, D.B., 2002. Wind driven general circulation of the Mediterranean Sea simulated with a spectral element ocean model. Dynamics of Atmospheres and Oceans 35, 97-130.

Molfino, B., McIntyre, A., 1990a. Nutricline variation in the equatorial Atlantic coincident with the Younger Dryas. Paleoceanography 5 (6), 997-1008.

Molfino, B., McIntyre, A., 1990b. Precessional forcing of nutricline dynamics in the Equatorial Atlantic. Science 249, 766-769.

Morán, X.A.G., Taupier-Letage, I., Vazquez-Dominguez, E., Ruiz, S., Arin, L. Raimbault, P., Estrada, M., 2001. Physical-biological coupling in the Algerian Basin (SW Mediterranean): influence of mesoscale instabilities on the biomass and production of phytoplankton and bacterioplankton. Deep-Sea Research 48, 405-437.

Moreno, A., Cacho, I., Canals, M., Grimalt, J.O., Sánchez-Goñi, M.F., Shackleton, N. Sierro, F.J., 2005. Links between marine and atmospheric processes oscillating on a millennial time-scale: a multi-proxy study of the last 50,000 yr from the Alboran Sea (Western Mediterranean Sea). Quaternary Science Reviews 24, 1623-1636.

Numberger, L.D., Kucera, M., Schulz, H., 2010. Eastern Mediterranean planktonic foraminifera assemblage dynamics during MIS 11. Forams 2010, International Symposium on Foraminifera, Rheinische Friedrich-Wilhelms-Universität Bonn, Germany, September 5-10, 2010, p. 148, Abstract.

Okada, H., Wells, P., 1997. Late Quaternary nannofossil indicators of climate change in two deep-sea cores associated with the Leeuwin Current off Western Australia. Palaeogeography, Palaeoclimatology, Palaeoecology 131, 413-432.

Oppo, D.W., McManus, J.F., Cullen, J.L., 1998. Abrupt climate events 500000 to 340 000 years ago: evidence from subpolar North Atlantic sediments. Science 279 1335-1338.

Petit, J.R., Jouzel, J., Raynaud, D., Barkov, N.I., Barnola, J.M., Basile, I., Bender, M. Chappellaz, J., Davis, J., Delaygue, G., Delmotte, M., Kotlyakov, V.M., Legrand, M., Lipenkov, V., Lorius, C., Pépin, L., Ritz, C., Saltzman, E., Stievenard, M., 1999. Climate and atmospheric history of the past 420,000 years from the Vostok Ice Core, Antarctica. Nature 399, 429-436.

Pierre, C., Belanger, P., Saliège, J.F., Urrutianguer, M.J., Murat, A., 1999. Paleoceanography of the western Mediterranean during the Pleistocene: oxygen and carbon isotope records at Site 975. In: Zahn, R., Comas, M.C., Klaus, A. (Eds.), Proc. ODP, Sci. Results., 161: College Station, TX (Ocean Drilling Program), pp. 481-488.

Pinardi, N., Navarra, A., 1993. Baroclinic wind adjustement processes in the Mediterranean Sea. Deep-Sea Research II 40 (6), 1299-1326.

Pinardi, N., Arneri, E., Crise, A., Ravaioli, M., Zavatarelli, M., 2006. The physical sedimentary and ecological structure and variability of shelf areas in the Mediterranean Sea. In: Robinson, A.R., Brink, K. (Eds.), 2006. The Sea, vol. 14 Harvard University Press, Cambridge, USA, pp. 1243-1330.

POEM Group, 1992. General circulation of the Eastern Mediterranean. Earth Sciences Review 32, 285-309.

Pujos, A., Giraudeau, J., 1993. Répartition des Noelaerhabdaceae (nannofossiles calcaires) dans le Quaternaire moyen et supérieur des oceans Atlantique et Pacifique. Oceanologica Acta 16 (4), 349-362.

Rabitti, S., Bianchi, F., Boldrin, A., Da Ros, L., Socal, G., Totti, C., 1994. Particulate matter and phytoplankton in the Ionian Sea. Oceanologica Acta 17, 297-303.

Raffi, I., Backman, J., Rio, D., Shackleton, N.J., 1993. Early Pleistocene and late Pliocene nannofossil biostratigraphy and calibration to oxygen isotope stratigraphies from DSDP Site 607 and ODP Site 677. Paleoceanography 8, 387-404.

Raffi, I., Backman, J., Fornaciari, E., Pälike, H., Domenico, R., Lourens, L., Hilgen, F., 2006. A review of calcareous nannofossil astrobiochronology encompassing the past 25 million years. Quaternary Science Reviews 25, 3113-3137.

Robinson, A.R., Golnaraghi, M., Leslie, W.G., Artegiani, A., Hecht, A., Lazzoni, E., Michelato, A., Sansone, E.A., Theocharis, A., Unluata, U., 1991. Structure and variability of the Eastern Mediterranean general circulation. Dynamics of Atmospheres and Oceans 15, 215-240.

Robinson, A.R., Feliks, Y., Pinardi, N., 1992. Process studies and dynamical forecast experiments for the Eastern Mediterranean. In: Charnock, H. (Ed.), Proceedings of the Workshop held in La Spezia, Italy, September 1983. Reports in Meteorology and Oceanography, vol. 41. University of Harvard.

Robinson, A.R., Golnaraghi, M., 1993. Circulation and dynamics of the Eastern Mediterranean Sea, quasi-synoptic data-driven simulations. Deep-Sea Research 40 (6), 1207-1246.

Robinson, A.R., Sellschopp, J., Warn-Varnas, A., Anderson, L.A., Lermusiaux, P.F.J., 1999. The Atlantic Ionian Stream. Journal of Marine Systems 20, 129-156.

Roether, W., Manca, B.B., Klein, B., Bregant, D., Georgopoulos, D., Beitzel, V. Kovacevic, V., Lucchetta, A., 1996. Recent changes in Eastern Mediterranean deep waters. Science 271, 333-335.

Rohling, EJ. 1991. Shoaling of the eastern Mediterranean pycnocline due to reduction of excess evaporation: implications for sapropel formation. Paleoceanography $6,747-753$.

Rohling, E.J., Gieskes, W.W.C., 1989. Late Quaternary changes in Mediterranean Intermediate Water density and formation rate. Paleoceanography 4, 531-545.

Rohling, E.J., Hilgen, F.J., 1991. The eastern Mediterranean climate at times of sapropel formation: a review. Geologie en Mijnbouw 70, 253-264. 
Rohling, E.J., Cane, T.R., Cooke, S., Sprovieri, M., Bouloubassi, I., Emeis, K.-C., Schiebel, R., Kroon, D., Jorissen, F.J., Lorre, A., Kemp, A.E.S., 2002. African monsoon variability during the previous interglacial maximum. Earth and Planetary Science Letters 202, 61-75.

Rohling, E.J., Grant, K., Bolshaw, M., Roberts, A.P., Siddall, M., Hemleben, Ch, Kucera, M., 2009. Antarctic temperature and global sea level closely coupled over the past five glacial cycles. Nature Geosciance 2, 500-504.

Rohling, E.J., Braun, K., Grant, K., Kucera, M., Roberts, A.P., Siddall, M., Trommer, G., 2010. Comparison between Holocene and marine isotope stage-11 sea-level histories. Earth and Planetary Science Letters 291, 97-105.

Rossignol-Strick, M., Paterne, M., Bassinot, F., Emeis, K.-C., De Lange, G.J., 1998. An unusual mid-Pleistocene monsoon period over Africa and Asia. Nature 392, 269-272.

Roussenov, V., Stanev, E., Artale, V., Pinardi, N., 1995. A seasonal model of the Mediterranean Sea. Journal of Geophysical Research 100 (C7), 13515-13538.

Ruddiman, W.F., 2005. Cold climate during the closest stage 11 analog to recent millennia. Quaternary Science Reviews 24, 1111-1121.

Saavedra-Pellitero, M., Flores, J.A., Baumann, K.-H., Sierro, F.J., 2010. Coccolith distribution patterns in surface sediments of Equatorial and Southeastern Pacific Ocean. Geobios 43, 131-149. doi:10.1016/j.geobios.2009.09.004.

Samtleben, C., 1980. Die evolution der Coccolithophoriden -Gattung Gephyrocapsa nach Befunden im Atlantik. Paläontology Zhurnal 54, 91-127.

Sanvoisin, R., D’Onofrio, S., Lucchi, R., Violanti, D., Castradori, D., 1993. 1 Ma paleoclimatic record from the eastern Mediterranean-Marflux project: first result of a micropaleontological and sedimentological investigation of a long piston core from the Calabrian Ridge. Il Quaternario 6 (2), 169-188.

Sato, T., Takayama, T., 1992. A stratigraphically significant new species, Reticulofenestra asanoi (calcareous nannofossil). In: Ishizaki, K., Saito, T. (Eds.) Centenary of Japanese Micropaleontology. Terra Sci. Publ., Tokyo, pp. 457-460.

Shipboard Scientific Party, 1997. Site 1008/1009. In: Eberli, G.P., Swart, P.K. Malone, M.J., et al. (Eds.), Proc. ODP, Init. Repts., 166: College Station, TX (Ocean Drilling Program), pp. 347-373. doi:10.2973/odp.proc.ir.166.111.1997.

Siegenthaler, U., Stocker, T.F., Monnin, E., Lüthi, D., Schwander, J., Stauffer, B., Raynaud, D., Barnola, J.-M., Fischer, H., Masson-Delmotte, V., Jouzel, J., 2005. Stable carbon cycle-climate relationship during the late Pleistocene. Science 310, 1313-1317.

Siokou-Frangou, I., Christaki, U., Mazzocchi, M.G., Montresor, M., Ribera d'Alcalà, M. Vaqué, D., Zingone, A., 2010. Plankton in the open Mediterranean Sea: a review. Biogeosciences 7, 1543-1586.

Sournia, A., 1973. La production primaire planctonique en Méditerranée, Newsletter, Cooperative Investigations in the Mediterranean, Special Issue 5, $128 \mathrm{pp}$.

Takahashi, K., Okada, H., 2000. The paleoceanography for the last 30,000 years in the southeastern Indian Ocean by means of calcareous nannofossils. Marine Micropaleontology 40, 83-103.
Takayama, T., Sato, T., 1987. Coccolith biostratigraphy of the North Atlantic Ocean, DSDP Leg 94. In: Ruddiman, W.F., Kidd, R.B., Thomas, E. (Eds.), DSDP Init. Reports 94. Government Printing Office, Washington, DC, U.S, pp. 651-702.

Tarantino, F., Afferri, A., Bergami, C., Capotondi, L., De Lange, G., Ferraro, L., Foresi, L.M., Girone, A., Lirer, F., Lourens, L., Maiorano, P., Marino, M., Pelosi, N., Vallefuoco, M., Verducci, M., 2011. High resolution paleoenvironmental variability in the Ionian Sea (Core KC01B) through MIS 9-13. In: Sierro, F.J., González-Delgado, J.A. (Eds.), Joint RCMNS - RCANS Interim Colloquium, Salamanca. September 21st to 23rd, 2011-Climate Changes, Bioevents and Geochronology in the Atlantic and Mediterranean over the last $23 \mathrm{Myr}$ Abstracts Book, p. 222.

Thiedig, F.M., Oezen, D., El-Chair, M., Geyh, M.M., 2000. The absolute age of the Quaternary lacustrine limestone of the Al Mahruqah formation-Murzuk Basin, Libya. In: Sola, M.A., Worsley, D. (Eds.), Geological Exploration in the Murzuk Basin. Elsevier, Amsterdam, pp. 89-116.

Weaver, P.P.E., 1993. High resolution stratigraphy of marine Quaternary sequences In: Hailwood, E.A. (Ed.), High Resolution Stratigraphy. Geological Society Special Publication, London, pp. 137-153.

Winter, A., Jordan, R.W., Roth, P.H., 1994. Biogeography of living Coccolithophores in ocean waters. In: Winter, A., Siesser, W.G. (Eds.), Coccolithophores. Cambridge University Press, London, pp. 161-178.

Wu, G., Yasuda, M.K., Berger, W.H., 1991. Late Pleistocene carbonate stratigraphy on Ontong-Java Plateau in the western equatorial Pacific. Marine Geology 99, 135-150.

Wüst, G., 1961. On the vertical circulation of the Mediterranean Sea. Journal of Geophysical Research 66, 3261-3271.

Young, J.R., 1994. The functions of coccoliths. In: Winter, A., Siesser, W.G. (Eds.), Coccolithophores. Cambridge University Press, London, pp. 63-82.

Ziveri, P., Thunell, R.C., Rio, D., 1995. Export production of coccolithophores in an upwelling region: results from San Pedro Basin, Southern California Borderlands. Marine Micropaleontology 24, 335-358.

Ziveri, P., Rutten, A., de Lange, G.J., Thomson, J., Corselli, C., 2000. Presentday coccolith fluxes recorded in central Eastern Mediterranean sediment traps and surface sediments. Palaeogeography, Palaeoclimatology, Palaeoecology 158, 175-195.

Ziveri, P., Thunell, R.C., 2000. Coccolithophore export production in Guaymas Basin, Gulf of California: response to climate forcing. In: Ganssen, G., Wefer, G. (Eds.), Particle Fluxes and Their Preservation in Deep Sea Sediments. Deep-Sea Reserach II, vol. 47, pp. 2073-2100.

Ziveri, P., Baumann, K.-H., Boeckel, B., Bollmann, J., Young, J., 2004. Biogeography of selected Holocene coccoliths in the Atlantic Ocean. In: Thierstein, H.R., Young, J.R. (Eds.), Coccolithophores from Molecular Processes to Global Impact. Springer, Berlin, pp. 400-452. 